US Army Corps of Engineers ${ }_{\circledast}$

Engineer Research and

Development Center

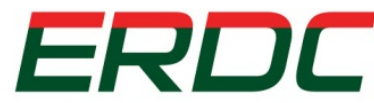

INNOVATIVE SOLUTIONS for a safer, better world

\title{
Inventory and Evaluation for Fort Riley Elementary School (\#104) and Custer Hill Elementary School (\#6344), Fort Riley, Kansas
}

Susan I. Enscore, Ellen R. Hartman, and Julie L. Webster

May 2017

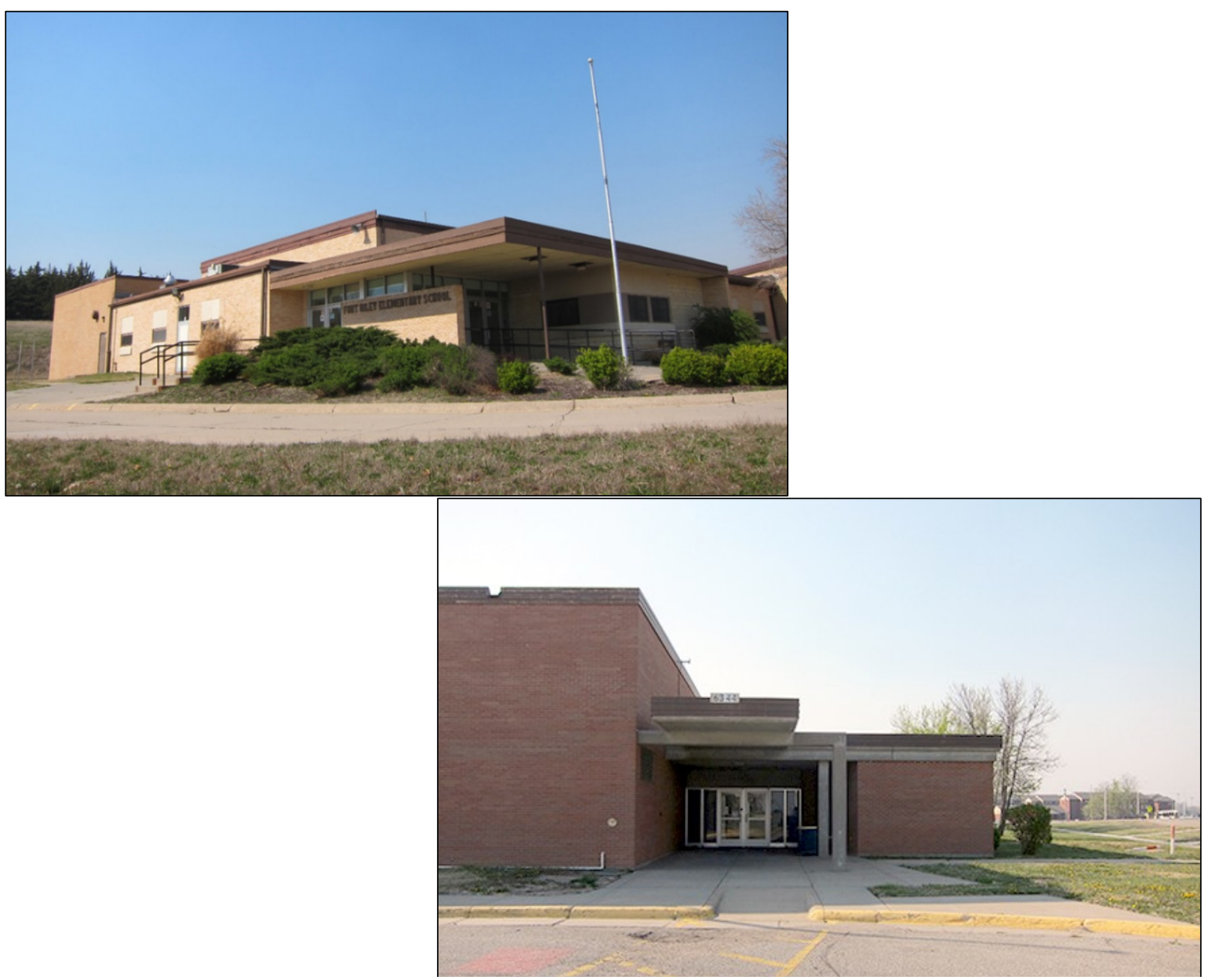


The U.S. Army Engineer Research and Development Center (ERDC) solves the nation's toughest engineering and environmental challenges. ERDC develops innovative solutions in civil and military engineering, geospatial sciences, water resources, and environmental sciences for the Army, the Department of Defense, civilian agencies, and our nation's public good. Find out more at www.erdc.usace.army.mil.

To search for other technical reports published by ERDC, visit the ERDC online library at http://acwc.sdp.sirsi.net/client/default.

Cover Photo. Fort Riley Elementary School (top) and Custer Hill Elementary School (bottom) (ERDC-CERL, 2016). 


\section{Inventory and Evaluation for Fort Riley Elementary School (\#104) and Custer Hill Elementary School (\#6344), Fort Riley, Kansas}

Susan I. Enscore, Ellen R. Hartman, and Julie L. Webster

Construction Engineering Research Laboratory

U.S. Army Engineer Research and Development Center

2902 Newmark Drive

Champaign, IL 61822

Final Report

Approved for public release; distribution is unlimited.

Prepared for Cultural Resources Office

Conservation Branch,-Environmental Division

Fort Riley, Kansas 66442

Under Project 453125, "Fort Riley Building Inventory Update 1964-1974" 


\section{Abstract}

This report documents an architectural survey and evaluation of two former school buildings at Fort Riley, Kansas, constructed in 1952 and 1963. This report includes a concise historic context, an architectural description and history for each building, and a determination of each building's eligibility to the National Register of Historic Places (NRHP). The Fort Riley Elementary School and the Custer Hill Elementary School were evaluated against relevant criteria for the existing historical themes related to Fort Riley and also against relevant criteria for the NRHP Multiple Property Historic District: Historic Public Schools of Kansas. It was found that both the Fort Riley Elementary School and the Custer Hill Elementary School did not meet significance criteria for eligibility to the NRHP, and are therefore recommended to be not eligible to the NRHP.

DISCLAIMER: The contents of this report are not to be used for advertising, publication, or promotional purposes. Citation of trade names does not constitute an official endorsement or approval of the use of such commercial products. All product names and trademarks cited are the property of their respective owners. The findings of this report are not to be construed as an official Department of the Army position unless so designated by other authorized documents. 


\section{Contents}

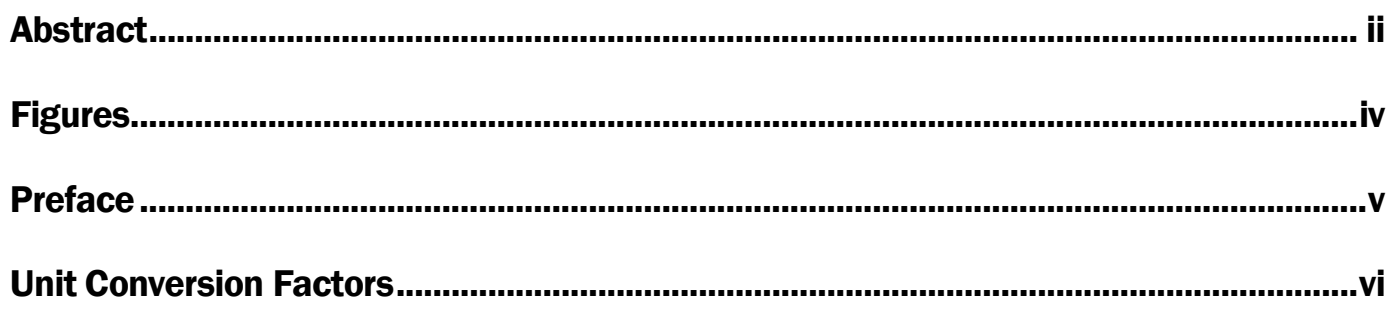

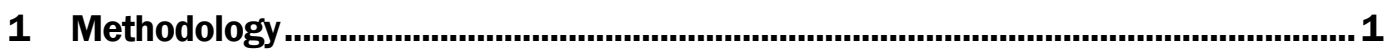

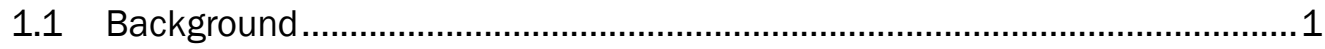

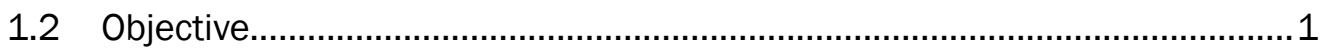

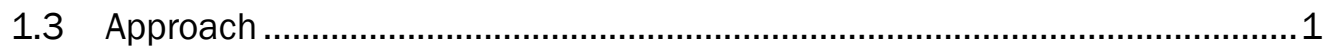

1.3.1 Site visits for architectural inventory and research ............................................ 2

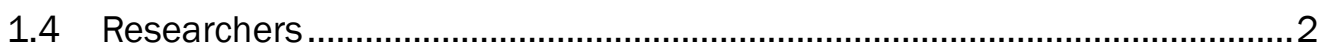

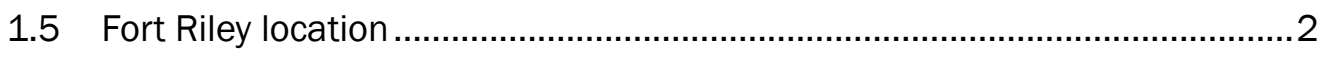

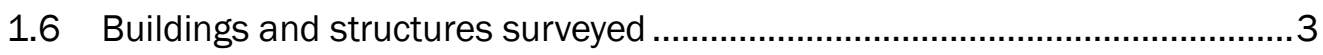

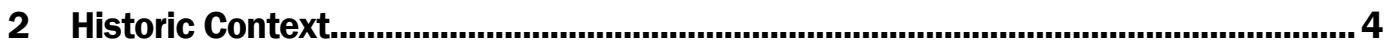

2.1 Public schools at Fort Riley and the Geary County School District................. 4

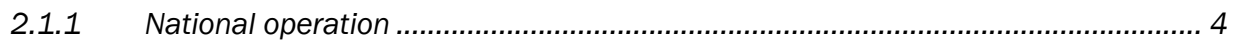

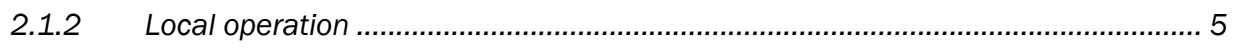

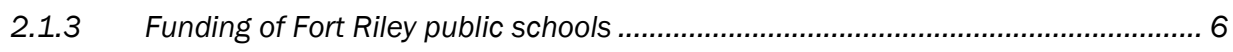

2.1.4 History of Fort Riley Elementary School (\#104) .................................................... 7

2.1.5 History of the Custer Hill Elementary School (\#6344)........................................... 8

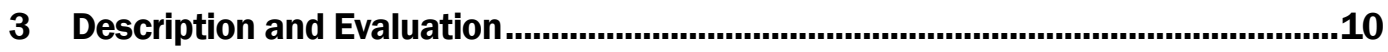

3.1 Fort Riley Elementary School (\#104) …....................................................10

3.2 Custer Hill Elementary School (\#6344) ....................................................10

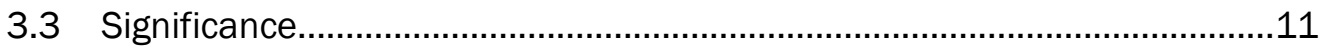

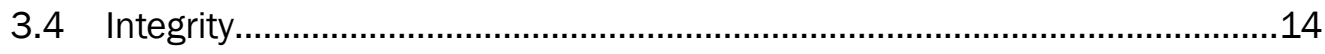

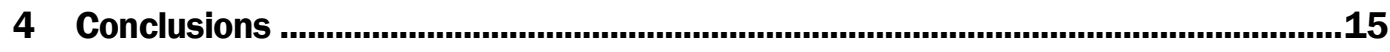

4.1 Determinations of eligibility ..............................................................15

4.1.1 Fort Riley Elementary School (\#104)................................................................... 15

4.1.2 Custer Hill Elementary School (\#6344) ................................................................ 15

References.....................................................................................................................17

Appendix A: Inventory Forms for Facility \#104 and Facility \#6344 at Fort

Riley, Kansas .......................................................................................................19

\section{Report Documentation Page}




\section{Figures}

\section{Figures}

Figure 1. Custer Hill Elementary School, 1963 (The Junction City Union, 22

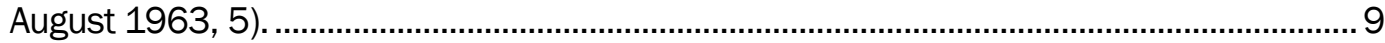




\section{Preface}

This study was conducted for the Cultural Resources Office, Conservation Branch, Environmental Division, Fort Riley, Kansas, as the second part of Project Number 453125, "Fort Riley Building Inventory Update 19641974," funded by Military Interdepartmental Purchase Request (MIPR) \#10697109. The technical monitor was Ms. Theresa de la Garza, Cultural Resources Manager, Fort Riley, Kansas.

The work was performed by the Land and Heritage Conservation Branch (CNC) of the Installations Division (CN), U.S. Army Engineer Research and Development Center, Construction Engineering Research Laboratory (ERDC-CERL). At the time of publication, Dr. Michael Hargrave was Chief, CEERD-CNC, and Ms. Michelle Hanson was Chief, CEERD-CN. The Deputy Director of ERDC-CERL was Dr. Kirankumar Topudurti, and the Director was Dr. Ilker Adiguzel.

The authors would like to acknowledge the following Fort Riley Directorate of Public Works personnel: Ms. Theresa de la Garza, Cultural Resource Manager, Environmental Division; Mr. Dave Young, Engineering Technician, Engineering Division; and Ms. Paula Fultz, Real Property Accountable Officer, Master Planning Division for their assistance during the research phase of this project. Dr. Robert Smith, Museum Director under the Center for Military History also deserves acknowledgement. Their combined expertise and generous access to records enabled the project team to complete their fieldwork successfully and in a timely manner.

COL Bryan S. Green was the Commander of ERDC, and Dr. David W. Pittman was the Director. 
ERDC/CERL TR-17-14

vi

Unit Conversion Factors

\begin{tabular}{|l|l|l|}
\hline Multiply & \multicolumn{1}{|l|}{ By } & To Obtain \\
\hline acres & $4,046.873$ & square meters \\
\hline miles (U.S. statute) & $1,609.347$ & meters \\
\hline square feet & 0.09290304 & square meters \\
\hline
\end{tabular}




\section{Methodology}

\subsection{Background}

The U.S. Congress codified the National Historic Preservation Act of 1966 (NHPA), ${ }^{1}$ the nation's most effective cultural resources legislation to date, in order to provide guidelines and requirements for preserving tangible elements of the nation's past. This widespread preservation was done primarily by creating the National Register of Historic Places (NRHP) in 1966. Contained within the NHPA (Sections 110 and 106) are requirements for federal agencies to address their historic properties, which are defined as "any prehistoric or historic district, site, building, structure, or object included on, or eligible for inclusion on, the National Register, including artifacts, records, and material remains relating to the district, site, building, structure, or object." ${ }^{2}$ Section 110 requires federal agencies to inventory and evaluate their cultural resources. Section 106 requires the determination of effect of federal undertakings on properties deemed eligible, or at a level of maturity to require evaluation for eligibility to the NRHP. Fulfilling Section 110 obligations allows federal agencies to be better prepared to make determinations of effect under Section 106.

\subsection{Objective}

The objectives of this work were to (a) inventory two of the schools on Fort Riley, Kansas; (b) research their history; and (c) assess the eligibility of these buildings according to NRHP guidelines.

\subsection{Approach}

As per Section 110 of the NHPA, Fort Riley needs to evaluate all of its buildings and structures potentially eligible for the NRHP. Under a Military Interdepartmental Purchase Request (MIPR) \#10697109, the Engineer Research and Development Center's Construction Engineering Research Laboratory (ERDC-CERL) was retained to undertake the project

\footnotetext{
1 U.S. Congress, National Historic Preservation Act, as amended, PL 89-665, 54 U.S.C. (Washington, DC: U.S. Congress, 1996).

2 Ibid., Section 300308.
} 
by completing inventories and determinations of eligibility for the Fort Riley properties. The work is being reported in two parts, with this report being the second of the two parts. A broader range of building types was evaluated in the first part of the project's work, which is reported in a forthcoming 2017 ERDC-CERL technical report. That report contains a more comprehensive historic context of Fort Riley due to the broader range of building types surveyed under the first part of this project.

\subsubsection{Site visits for architectural inventory and research}

The ERDC/CERL researchers conducted fieldwork at Fort Riley in April 2016. The fieldwork conducted during those trips included physical inventories of the two buildings as well as archival research in the following Directorate of Public Works (DPW) offices: Environmental Division, Engineering Division, and the Master Planning Division. Archival research was also conducted at the Fort Riley Cavalry and 1st Infantry Division Museums under the Center for Military History, and at the Junction City Public Library.

The Fort Riley Cultural Resources Office provided the ERDC-CERL project team with information on the buildings needing to be inventoried and evaluated. Both field notes and digital photographs were taken to provide the data necessary to describe and evaluate each building (see Appendix A).

\subsection{Researchers}

This project was conducted by the U.S. Army Corps of Engineers' research laboratory, ERDC-CERL, based in Champaign, Illinois. The research team included Susan Enscore, PhD, as project manager and historian; Julie Webster, Master of Architecture, as researcher; and Ellen Hartman, Master of Landscape Architecture, as researcher.

\subsection{Fort Riley location}

Fort Riley is located in the northeastern part of Kansas (about 135 miles west of Kansas City and 130 miles north-northeast of Wichita). It was established in 1852 at the site where the Smoky Hill and Republican Rivers join to form the Kansas River, just east and a little north of Junction City. 


\subsection{Buildings and structures surveyed}

Only two of the school buildings at Fort Riley were surveyed for this report: Fort Riley Elementary School (\#104) and Custer Hill Elementary School (\#6344). Due to their distinct nature as public schools, the evaluation report for these two buildings is provided separately from the larger study inventorying and evaluating military facilities at Fort Riley constructed between 1964 and 1974. The larger study results are contained in another ERDC-CERL report to be published in 2017 that is titled, "Fort Riley Building Inventory and Evaluation, 1964-1974." 


\section{Historic Context}

The history of the public schools at Fort Riley is related to that of the local school district. Due to the national scope of public schools on U.S. Army bases, however, the Fort Riley schools' history diverges in several important ways - judicial, fiscal, spatial, and militarily. This historic context provides a chronological look at the base's history of public school development relative to the local public school system's development, then discusses the history of the two Fort Riley schools under evaluation.

\subsection{Public schools at Fort Riley and the Geary County School District}

\subsubsection{National operation}

The first school for dependents on a military installation in the Army was an elementary school established at the West Point Military Academy prior to 1816. This precedent of an installation taking responsibility for the education of military dependents when there was no available public education in the local area remained in action until 1950.3 That year, federal legislation (Public Law No. 81-874, Section 6) placed responsibility for the funding, operation, and maintenance of these schools under the Secretary of Education's office. This was only applicable if "state laws prohibited tax revenues of the state or any political subdivision of the state to be expended for the free public education of children residing on Federal property," and "education systems within the local communities were judged unable to provide a suitable free public education for the children residing on Federal property before a Section 6 school could be transferred to a Local Education Authority (LEA)."4 The 1950 consolidation allowed for children on military installations to attend integrated schools on post, as the Army was formally an integrated force at that point, whereas the local schools may have been segregated. The preference for the federal schools to be transferred to LEAs has grown over time as schools were integrated and local populations around installations grew large enough to support

\footnotetext{
3 U.S. Department of Defense Education Activity, “DoDEA Americas History,” http://www.dodea.edu/Americas/aboutAm/amHistory.cfm.

4 ibid.
} 
their own school systems. The transfers were mostly complete by the 1970s. 5

\subsubsection{Local operation}

The local history of schools at Fort Riley differed somewhat from the national scenario. The Junction City Board of Education accepted responsibility for educating children on Fort Riley in 1942. It is likely that the growth of the local area around the installation, due to the influx of World War II military personnel and civilian employees, enabled the Board to take this step. ${ }^{6}$ In 1945, legislation was passed that allowed the Fort Riley students to attend city schools with no tuition costs and reimbursement made from state school funds. This changed in 1950 with the federal consolidation of federal schools, and funding for the operational expenses of students at Fort Riley was provided through a contract where Fort Riley paid \$71.32 per year/per student to the Junction City Board of Education. ${ }^{7}$ When schools were constructed on Fort Riley (with congressional funds), they were turned over to the Board of Education for operation, and the Board was granted a lease for the land on which the schools were located. ${ }^{8}$

In 1965, the Junction City School District became the Geary County Unified School District No. 475, serving the schools of Junction City, Milford, and Grandview Plaza. All grades excepting high school were taught in schools located on the installation. Fort Riley students attended upper grades at the Junction City High School, as it was the only high school in the district. 9 By 1968, there were four public elementary schools and one junior high school on Fort Riley that were operated by the School District, with a total capacity of 1,540 students, rising to 2,582 by June $1971 .^{10}$ In contrast, in 1968 Junction City had six elementary schools, one public junior high school, one public senior high school, one Lutheran School, and one Catholic School. ${ }^{11}$ Legal titles to all public schools on Fort Riley were

\footnotetext{
5 ibid.

6 Unified School District No. 475, Geary County, Kansas, "History of USD 475," https://www.usd475.org/enrollment/SitePages/Our\%20History.aspx.

7 ibid.

8 “Ft. Riley Schools Operated By Geary County," The Fort Riley Post, 20 August 1971, 13.

9 “Junction City Operates Fort Riley Schools," Fort Riley Post, 9 February 1968, page unknown.

10 lbid.

$11 \mathrm{lbid}$; It is not known how many schools the School District had at that time in Milford and Grandview Plaza.
} 
transferred to the Geary County Unified School District No. 475 in 1989, through legislation sponsored by U.S. Senator Bob Dole of Kansas. ${ }^{12}$ Subsequently, the real property rolls at Fort Riley listed the facilities as "Not Government Owned," and active schools on the post retain this designation today. ${ }^{13}$ The public schools at Fort Riley admit children of military parent(s) living off post and within Unified School District (USD) 475 as well as children of Department of the Army civilian employees within USD 475 , both on a space-available basis.

\subsubsection{Funding of Fort Riley public schools}

One of the primary ways in which the schools on the installation differ from the schools in the surrounding local area is the source of funds for both construction and operation, with decisions concerning Fort Riley made on a national level and with national-level funds. Decisions to construct or expand Fort Riley's schools were based not on the needs of the local county, but on the projected or occurring growth of installation personnel in response to national military missions, such as the expansion of Fort Riley's military education program during the Korean War, and the decision for Fort Riley to become the home base to the 1st Infantry Division in 1955. The first large-scale national family housing program for the Army got underway with the passage of the Wherry Bill in 1949. At Fort Riley, 400 housing units were completed in June $1951 .{ }^{14}$ These units enabled a large number of families to procure housing on post instead of in the local communities. At the same time, Fort Riley's total population was growing through training recruits for the Korean War and an expansion of Fort Riley's military education program. The need for on-post primary education facilities for the children of military personnel was one of the results of these events.

A similar situation occurred in the early 1960 . As the 1st Infantry Division shifted from a recruit training mission to a combat-ready division in 1961, the numbers of enlisted recruits diminished, and an increase was seen in the number of older, married soldiers. ${ }^{15}$ By early 1962, Fort Riley had a

\footnotetext{
12 Unified School District No. 475, Geary County, Kansas, “History of USD 475.”

13 Fort Riley Real Property Records, Real Property Office, Department of Public Works, Fort Riley, Kansas.

14 "New Housing Units Nearing Completion," The Junction City Union, 5 December 1950, 1; “Open Post Housing," The Junction City Union, 12 January 1951, 1.

15 “Kansas's Sixth Largest City Altered By Crisis," The Fort Riley Post, 9 February 1962, 1.
} 
permanent population of 27,026, enough to make it the sixth largest "city" in Kansas. ${ }^{16}$ Additional family housing was required, and a new national housing program codified in the Capehart Housing Act of 1955 was utilized to secure a large number of family quarters for the installation. By 1963 , three large Capehart projects were completed on Custer Hill at Fort Riley, resulting in the addition of 867 housing units. ${ }^{17}$ Student enrollments at the existing Fort Riley Elementary School were above 1,300 by January 1962, and total need was expected to be 1919 for elementary and 498 for junior high after the Capehart housing was occupied. ${ }^{18}$ Not waiting until construction was complete, funding had been secured several years earlier, and construction was underway by early 1962 for a new elementary school and junior high school. ${ }^{19}$

In terms of operating costs, the federal government was also involved in a way the Geary Count's Unified School District was not. Federal government funds made up one of the three sources of funding the district received for operating the schools, with other funds coming from the State of Kansas and the local school district itself. The federal funds were provided on a prorated basis for every student from federally employed families living on post. In 1970, that amounted to $\$ 422.62$ per student. State funds were also used for operating costs associated with Fort Riley schools, contributing \$261.58 per student in 1970. No local funds were used for operation of the Fort Riley schools. ${ }^{20}$

\subsubsection{History of Fort Riley Elementary School (\#104)}

In 1951, Geary County School Board received a lease from Fort Riley for a five-acre parcel of land for the construction of a public school. ${ }^{21}$ The land was located at the northwestern edge of the Main Post and on the far side of Huebner Road (Hwy. 18), the main thoroughfare through the installation. ${ }^{22}$ It is not known which architectural firm designed the building. The

\footnotetext{
16 “Fort Riley Kansas Sixth Largest 'City' With 27,026 on Post," The Junction City Union, 2 February 1962, 1.

17 "Ground Breaking Marks Start of Housing Project in Custer Hill Area," The Fort Riley Post, 7 April 1961, 1.

18 "Kansas's Sixth Largest City Altered By Crisis," The Fort Riley Post, 9 February 1962, 1.

19 ibid., 16; "New Construction Has Added 62 Rooms to Area Schools," The Junction City Union, 22 August 1963, 1.

20 "Ft. Riley Schools Operated By Geary County," 13.

21 Unified School District No. 475, Geary County, Kansas, "History of USD 475."

22 ibid.
} 
Fort Riley Elementary School opened in 1952 with Margaret Waddell as the first principal. ${ }^{23}$ Legal title to the school was transferred to the Geary County Unified School District No. 475 in 1989. ${ }^{24}$ A new elementary school was constructed in 2014 in the Forsyth housing area, and it opened in August 2015.25 This made the Fort Riley Elementary School redundant. In December 2015, ownership of Facility 104 was transferred at no cost from the school district back to Fort Riley. ${ }^{26}$ The land for Facility 104 had been leased from Fort Riley, and upon transferal of the building, the land was returned to Fort Riley. The Fort Riley Elementary School was closed at the end of the 2014-15 academic year.

\subsubsection{History of the Custer Hill Elementary School (\#6344)}

Federal funds from the Housing and Home Finance Agency were allotted for the construction of Custer Hill Elementary School (along with a new junior high school) in 1961. The firm of Howells, Hale and Wohlberg, of Topeka, Kansas, prepared plans and specification for the school's construction. The firm had recently designed a school in Junction City. ${ }^{27}$ The accepted construction bid was submitted by N.F. English Construction Company of Hutchinson, Kansas. ${ }^{28}$ The new school was constructed for use by the families moving into 857 new housing units near the location for the school, and it was planned to be ready for the 1963-64 school year. ${ }^{29}$ The Custer Hill Elementary School opened in August 1963, with Clarke Schiller as the principal (Figure 1). ${ }^{30}$ Legal title to the school was transferred to the Geary County Unified School District No. 475 in 1989.31 A new elementary school was constructed in 2014 in the Forsyth housing area, and it opened in August 2015. $3^{2}$ This made the Custer Hill Elementary School redundant. In December 2015, ownership of the facility was transferred at no cost from the School District back to Fort Riley. The land

\footnotetext{
23 ibid.

24 Unified School District No. 475, Geary County, Kansas, "History of USD 475."

25 ibid.

26 Fort Riley Real Property Records.

27 “U.S. Funds Are Allocated for 2 Schools on Post," The Junction City Union, 23 June 1961, 1.

28 “Low Bid on School is \$448,642," The Junction City Union, 20 July 1962, 1.

29 "Custer Hill Elementary School," The Junction City Union, 22 August 1963, 5; "U.S. Funds Are Allocated for 2 Schools on Post," 1 .

30 Unified School District No. 475, Geary County, Kansas, "History of USD 475."

31 ibid.

32 ibid.
} 
for Facility 6344 had been leased from Fort Riley, and upon transferal of the building, the land was returned to Fort Riley. The Custer Hill Elementary School was closed at the end of the 2014-2015 school year.33

Figure 1. Custer Hill Elementary School, 1963

(The Junction City Union, 22 August 1963, 5).

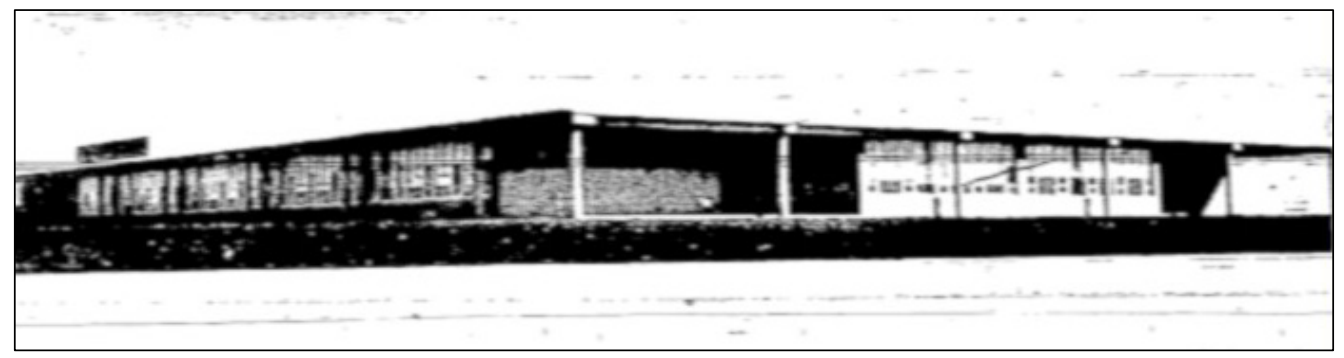

33 "Board of Education Makes Decision on Custer Hill Elementary School," JC Post, 21 April 2014 , http://www.jcpost.com/2014/04/21/board-of-education-makes-decision-on-custer-hill-elementaryschool/ 


\section{Description and Evaluation}

\subsection{Fort Riley Elementary School (\#104)}

Fort Riley Elementary School was constructed in 1952 at a cost of $\$ 295,595$. The irregular plan, one-story facility was constructed of concrete block clad in brick, and contains 40,593 square feet. It has a continuous concrete foundation, and built-up flat roofs at various levels with roof ventilation stacks. The areas above the windows are covered with stucco Dryvit. Aluminum storefront windows are located at the entrance, and the building also has single-hung and double-sliding aluminum windows. Single, metal louvered vents are interspersed in the walls. Doors are single and double style; some are aluminum and some are steel. A recessed entry porch with an accessibility ramp and concrete stairs is located at the main entrance, and there is an entry porch at the southeast corner with concrete stairs.

When constructed, the Fort Riley Elementary School contained 23,400 square feet. A 6,100 square foot addition was constructed in 1954 at a cost of $\$ 196,975$, and a second addition to house a kitchen and music room was built in 1960 at a cost of $\$ 53,607$ for 1,500 square feet. It is not known when the additional 9,593 square feet were added to reach the current 40,593 square feet. The original ribbon window openings were infilled with stucco Dryvit. Windows were blocked at the angled entry and at the gym.

\subsection{Custer Hill Elementary School (\#6344)}

Custer Hill Elementary School was constructed in 1963 at a cost of $\$ 448,642$ and contains 35,545 square feet. The irregular plan, one-story facility was constructed of concrete block clad in brick, and poured concrete beams/columns at the entry. It has a continuous reinforced concrete foundation and built-up flat roofs at various levels. The facility has aluminum coping and Dryvit sills. The building has exposed corner eaves and round corner columns. Double sliding aluminum windows are installed. Doors are single and double aluminum storefront, and steel flush single and double type. An open recessed porch at the main entry is constructed of poured concrete with chamfered concrete columns and an exposed frame/roof. There are recessed porches of poured concrete at both the 
northwest and southwest entries from the playground. A roof ladder is located at the gymnasium.

When constructed, the Custer Hill Elementary School contained 31,200 square feet. It is not known when the additional 4,345 square feet were added to reach the current 35,545 square feet. Doors and windows have been replaced. The main entry doors are original. The original ribbon window openings were infilled with stucco Dryvit when the windows were replaced. The north door opening has been blocked, as have the crawlspace openings.

\subsection{Significance}

For either of the schools to be determined significant, they must meet at least one of four NRHP criteria for significance: 34

A. Event-associated with events that have made a significant contribution to the broad patterns of our history; or

B. Person-associated with the lives of persons significant in our past; or

C. Design/Construction-embody the distinctive characteristics of a type, period, or method of construction, or that represent the work of a master, or that possess high artistic values, or that represents a significant and distinguishable entity whose components may lack individual distinction; or

D. Information Potential-yielded, or is likely to yield, information important in prehistory or history.

Research on the history of the Fort Riley Elementary School and the Custer Hill Elementary School concentrated on a search for significant events within the period from date of construction through 1968 (50 years ago).

Criterion A - There are eight historic themes potentially applicable to the Fort Riley Elementary School based on its era of construction, five related to Fort Riley military history and three related to Kansas public school history. During the period of the school's operation, the relevant military historical themes up through 1967 were: Combat Training and Army Schools;

\footnotetext{
34 NPS. National Register Bulletin \#15: How to Apply the National Register Criteria for Evaluation, 7.
} 
Army Aviation, Fixed and Rotary-Wing Training; Army Medicine: Hospital Integration; Operation Gyroscope; and Ground Combat Training for Vietnam. 35 Due to its later construction date, there are only two relevant military historical themes for the Custer Hill Elementary School: Combat Training and Army Schools; and Ground Combat Training for Vietnam. Significance under these five military history themes has been previously defined as properties directly related to the respective Fort Riley missions the themes encompass. As tertiary level support structures at Fort Riley, public schools were not directly related to any significant Fort Riley missions. The Fort Riley Elementary School and the Custer Hill Elementary School do not rise to the level of significance in representing these historic themes.

There is a historic district encompassing the Main Post at Fort Riley, and the Fort Riley Elementary School falls within its boundaries. The school's period of construction and use, however, is later than the district's period of significance; therefore, it does not contribute to the district under Criterion $\mathrm{A}$.

The facilities were also evaluated for NRHP eligibility under a statewide historic context supporting a multi-property nomination to the NRHP. The nomination, "Historic Public Schools of Kansas," bases significance under Criterion A on three historic themes: The American Education System (1700-1955), The Evolution of the Public School System in Kansas (1854-1955), and the Public School Buildings of Kansas (1854-1955). ${ }^{36}$ The first theme, The American Education System (1700-1955), describes the consolidation of schools in many states under a state system of organization. The "modern" era of public schools was initiated by this consolidation. This theme also ties the main growth in the number of schools to the post-World War II baby boom in the 1950s. 37 The schools at Fort Riley were consolidated into a Federal system that allowed local operation only under certain conditions. The period of greatest growth for public schools at Fort Riley came in the 1960s, as a result of national Army missions and family housing policies, and was not related to the local birth rate. The

\footnotetext{
351967 is chosen as the end of the period of significance as it marks 50 years from the present date.

36 Brenda R. Spencer, "Historic Public Schools of Kansas: National Register of Historic Places Multiple Property Documentation Form,” (Wamego, KS: Preservation Planning and Design, 2005), 1.

37 Ibid., 4.
} 
Fort Riley Elementary School and the Custer Hill Elementary School do not rise to the level of significance in representing this historic theme.

The second theme, The Evolution of the Public School System in Kansas (1854-1955), describes the major trends of public education in the state as an effort to equalize rural and urban schools in terms of support and quality of education, and the organization of school districts to enhance the equalization of education quality. State aid for Kansas public schools arrived through legislation in 1937, which greatly helped support rural schools and elementary education in general. ${ }^{8}$ School districts were consolidated upon passage of legislation in 1963, setting up unified districts with responsibility for all schools in a geographically defined area. 39 The public schools at Fort Riley were not as reliant on state aid as were the non-federally supported schools, so the issue of state aid was not as significant. The Fort Riley schools were little impacted by consolidation, as the students stayed on the installation and did not have to travel a significant distance from home to rural schools or to town or city schools. Local initiatives such as annexation facility consolidation did not impact the Fort Riley schools. In essence, the public schools at Fort Riley were part of the system, yet stood apart in many ways related to the unique history of Kansas public schools. The Fort Riley Elementary School and the Custer Hill Elementary School do not rise to the level of significance in representing this historic theme.

For the third theme, Public School Buildings of Kansas (1854-1955), significance rests on the architectural firm that designed the building. The NRHP nomination provides a list of firms significant at the national, state, and local levels for design of school facilities. The architectural firm responsible for the design of the Fort Riley Elementary School was not found in the archival material analyzed for this ERDC-CERL report. The architecture firm that designed the Custer Hill Elementary School, Howells, Hale and Wohlberg, of Topeka, Kansas, was not listed as significant in the NRHP nomination. The Fort Riley Elementary School and the Custer Hill Elementary School do not rise to the level of significance in representing this historic theme.

\footnotetext{
38 bid.,13.
}

39 bid., 14. 
Criterion B - The available historical records provided no indication that the surveyed properties were associated with the life of an individual significant in United States history.

Criterion C - The surveyed facilities do not individually characterize the distinctive characteristics of a type, period, or method of construction that is architecturally significant, they do not represent the work of a master (as specified in the multiple property nomination for Kansas public schools), nor do they possess high artistic values. They are not individually distinctive, and were not designed by architectural masters. Their designs do not possess any characteristics that would raise them to the level of significance as examples of architecture or building construction. The NRHP multiple property nomination for Historic Public Schools of Kansas lists country schools, town schools, and city schools as property types significant on a state or local level, distinguished by locale.40 Dependent schools on military installations such as Fort Riley do not meet any of the property types. Although the Fort Riley Elementary School lies within the Fort Riley Main Post Historic District, the school's architectural style and construction materials prevent it from being both compatible with and contributing to the district under Criterion $\mathrm{C}$.

Criterion D - The available historical records provided no indication that the study properties have yielded, or were likely to yield, any information important in prehistory or history beyond what the real property records, architectural drawings, and archival research have already yielded.

\subsection{Integrity}

Both the Fort Riley Elementary School and the Custer Hill Elementary School failed to rise to the level of historical significance necessary to qualify for listing on the NRHP. Thus, there is no need to determine the integrity of the facilities. Additionally, both facilities have undergone modifications with additions and large-scale window replacement that does not match the original masonry openings. 


\section{Conclusions}

\subsection{Determinations of eligibility}

\subsubsection{Fort Riley Elementary School (\#104)}

The Fort Riley Elementary School is recommended not eligible for listing in the NRHP, either individually or as a contributing resource to a historic district. It served as a support facility for educating children of military families on post, playing a tertiary role in the mission of the installation, and did not serve as a community center or other focal point at Fort Riley in a social or spatial sense. Although a part of the Geary County Unified School District No. 475, the schools on post differed in funding, urban-rural perspective, and federal/state/local policies for district system components from the surrounding schools. The Fort Riley schools were more aligned with important national trends than with important state or local trends. There is no indication that the surveyed property was associated with the life of an individual significant in United States history. Facility \#104's design does not possess any characteristics that would raise it to the level of significance as an example of architecture or building construction under the "Historic Public Schools of Kansas" NRHP multiple property nomination. There is no indication that the surveyed property has yielded, or is likely to yield, any information important in prehistory or history beyond what the real property records, architectural drawings, and archival research have already yielded.

\subsubsection{Custer Hill Elementary School (\#6344)}

The Custer Hill Elementary School is recommended not eligible for listing in the NRHP, either individually or as a contributing resource to a historic district. It served as a support facility for educating children of military families on post, playing a tertiary role in the mission of the installation, and did not serve as a community center or other focal point at Fort Riley in a social or spatial sense. Although considered a part of the Geary County Unified School District No. 475, the schools on post differed in funding, urban-rural perspective, and federal/state/local policies for district system components from the surrounding schools. The Fort Riley schools were more aligned with important national trends than with important state or local trends. There is no indication that the surveyed property was associated with the life of an individual significant in United States history. Facility \#6344's design does not possess any characteristics that would raise 
it to the level of significance as an example of architecture or building construction under the "Historic Public Schools of Kansas" NRHP multiple property nomination. There is no indication that the surveyed property has yielded, or is likely to yield, any information important in prehistory or history beyond what the real property records, architectural drawings, and archival research have already yielded. 


\section{References}

"Board of Education Makes Decision on Custer Hill Elementary School." JC Post (online news hub), 21 April 2014, http://www.jcpost.com/2014/o4/21/board-ofeducation-makes-decision-on-custer-hill-elementary-school/.

“Custer Hill Elementary School.” The Junction City Union, 22 August 1963, 5.

"Fort Riley Kansas Sixth Largest 'City' With 27,026 on Post.” The Junction City Union, 2 February 1962, 1.

Fort Riley Real Property Records, Real Property Office, Department of Public Works, Fort Riley, Kansas.

"Ground Breaking Marks Start of Housing Project in Custer Hill Area." The Fort Riley Post, 7 April 1961, 1.

“Kansas's Sixth Largest City Altered By Crisis.” The Fort Riley Post, 9 February 1962, 1.

“Low Bid on School is \$448,642." The Junction City Union, 20 July 1962, 1.

“New Housing Units Nearing Completion." The Junction City Union, 5 December 1950, 1.

"New Construction Has Added 62 Rooms to Area Schools." The Junction City Union, 22 August 1963, 1.

NPS. National Register Bulletin \#15: How to Apply the National Register Criteria for Evaluation. Washington, DC: U.S. Department of the Interior, National Park Service, 1991.

“Open Post Housing.” The Junction City Union, 12 January 1951, 1.

Spencer, Brenda R. "Historic Public Schools of Kansas: National Register of Historic Places Multiple Property Documentation Form.” Wamego, KS: Preservation Planning and Design, 2005.

Unified School District No. 475, Geary County, Kansas. "History of USD 475." https://www.usd475.org/enrollment/SitePages/Our\%20History.aspx.

U.S. Department of Defense Education Activity, "DoDEA Americas History,” http://www.dodea.edu/Americas/aboutAm/amHistory.cfm.

"U.S. Funds Are Allocated for 2 Schools on Post." The Junction City Union, 23 June 1961, 1. 
(This page intentionally blank.) 


\section{Appendix A: Inventory Forms for Facility \#104 and Facility \#6344 at Fort Riley, Kansas}

The following pages reproduce inventory forms prepared for Facility \#104 and Facility \#6344 at Fort Riley, Kansas. 
Building\#: 104

\section{A. FORT RILEY HISTORIC BUILDING INVENTORY Exterior Survey and National Register Evaluation}

\section{Identification}

\begin{tabular}{|c|c|c|c|}
\hline Current Building \#: & 104 & Owner: & Department of the Army \\
\hline Early Building \#s: & $342(1976)$ & Post Location: & Main Post \\
\hline Building Name: & $\begin{array}{l}\text { Fort Riley Elementary } \\
\text { School }\end{array}$ & Address: & Morris Avenue \\
\hline CATCODE: & 73046 & & \\
\hline Current Use: & (vacant) & & \\
\hline Early Use: & Elementary School & & \\
\hline
\end{tabular}

\section{National Register Eligibility}

\begin{tabular}{|c|c|}
\hline Eligibility Status: & Not Eligible \\
\hline Eligibility Type: & Integrity Aspects: \\
\hline Theme/District: & $\mathrm{n} / \mathrm{a}$ \\
\hline Significance: & $\begin{array}{l}\text { The Fort Riley Elementary school is recommended not eligible for } \\
\text { listing in the NRHP, either individually or as a contributing resource } \\
\text { to a historic district. It served as a support facility for educating } \\
\text { children of military families on post, playing a tertiary role in the } \\
\text { mission of the installation, and did not serve as a community center or } \\
\text { other focal point at Fort Riley in a social or spatial sense. Although } \\
\text { a part of the Geary County Unified School District No. 475, the schools } \\
\text { on post differed in funding, urban-rural perspective, and } \\
\text { federal/state/local policies for district system components from the } \\
\text { surrounding schools. The Fort Riley schools were more aligned with } \\
\text { important national trends than with important state or local trends. } \\
\text { There is no indication that the surveyed property was associated with } \\
\text { the life of an individual significant in United States history. } \\
\text { Facility \#lo4's design does not possess any characteristics that would } \\
\text { raise it to the level of significance as an example of architecture or } \\
\text { building construction under the "Historic Public Schools of Kansas" } \\
\text { NRHp multiple property nomination. There is no indication that the } \\
\text { surveyed property has yielded, or is likely to yield, any information } \\
\text { important in prehistory or history beyond what the real property } \\
\text { records, architectural drawings, and archival research have already } \\
\text { yielded. }\end{array}$ \\
\hline
\end{tabular}

\section{Sources of Information}

Fort Riley Directorate of Public Works (DPW) real property database; War Department Form 5-47, Real Property Record - Buildings; DA Form 2877, Real Property Record; DPW Building Directory (2011); drawings on file at Fort Riley DPW; and field observations

\section{Project Information}

Surveyors:

Affiliation:

Survey Dates:
Susan I. Enscore, Julie L. Webster \& Ellen R. Hartman

ERDC-CERL, PO BOx 9005, Champaign, IL 61826-9005

19-23 October 2015, 4-6 April 2016 
Building\#: 104

\section{Physical Description}

\begin{tabular}{|c|c|c|}
\hline Year Completed: & 1952 & Condition: \\
\hline Original Cost: & $\$ 295,595.00$ & $\begin{array}{l}\text { Minor/Reversible } \\
\text { Alterations }\end{array}$ \\
\hline Construction Type: & Permanent & Building Style: \\
\hline E-file Plan \#: & $\begin{array}{l}\text { 104_Floor_Plan_no_date_not } \\
\text { historic }\end{array}$ & Area (sqft): \\
\hline Original Plan \#: & unknown & Irregular \\
\hline Designer: & unknown & Stories (\#): \\
\hline Builder: & unknown & Basement: \\
\hline Foundation Matl: & $\begin{array}{l}\text { Continuous reinforced } \\
\text { concrete }\end{array}$ & $\begin{array}{l}\text { TYPE (shed); PITCH } \\
\text { (slight); MATL (built-up) }\end{array}$ \\
\hline Structural Material: & Concrete block & Roof \#2: \\
\hline Cladding Material: & $\mathrm{n} / \mathrm{a}$ & Roof \#3: \\
\hline Window \#1: & TYPE (sliding); GROUP (single & e); MATL (aluminum); LITES (2); ORIG (no) \\
\hline Window \#2: & TYPE (awning); GROUP (single) & ); MATL (aluminum); LITES (1/1); ORIG (no) \\
\hline Window \#3: & $\mathrm{n} / \mathrm{a}$ & \\
\hline Door \#1: & TYPE (flush); GROUP (single); & ; MATL (steel); ORIG (no) \\
\hline Door \#2: & TYPE (flush); GROUP (single); & ; MATL (steel); ORIG (yes) \\
\hline Door \#3: & TYPE (storefront); GROUP (dou & uble); MATL (aluminum); ORIG (no) \\
\hline Porch \#1: & $\begin{array}{l}\text { TYPE (recessed, open 2-riser } \\
\text { (concrete) }\end{array}$ & stoop, ramped); PLACE (front); MATL \\
\hline Porch \#2: & $\begin{array}{l}\text { TYPE (recessed, partially enc } \\
\text { corner); MATL (concrete) }\end{array}$ & closed, 8-riser stoop, ramped); PLACE (SE \\
\hline Porch \#3: & $\mathrm{n} / \mathrm{a}$ & \\
\hline Other Features: & $\begin{array}{l}\text { ARCHITECTURAL - Aluminum copi } \\
\text { Roof ladder; Pipe rails at fr } \\
\text { Concrete water basin in court } \\
\text { separation walls; Speaker sys } \\
\text { entry; Green gambrel shed (E) } \\
\text { transformer on concrete pad } \\
\text { rear with chain link for safe } \\
\text { south; remote parking (SW) of }\end{array}$ & $\begin{array}{l}\text { ing, gutters \& downspouts; Dryvit sills; } \\
\text { ront entry; Angled eaves; Boot scrape (NE); } \\
\text { tyard; Brick planter at SE corner; Fire } \\
\text { stem; LANDSCAPE - Chain link fence at SE } \\
\text { ); Concrete play areas (E); Electrical } \\
\text { (courtyard); Limestone retaining wall at } \\
\text { ety; Main entry plantings; Parking to } \\
\text { f building }\end{array}$ \\
\hline Alterations/Addns: & $\begin{array}{l}\text { Constructed } 6,100 \text { sqft additi } \\
\text { sqft kitchen and music room } \\
\text { unknown); Replaced doors \& wi } \\
\text { entry; Filled original ribbon } \\
\text { clerestory windows at gym. }\end{array}$ & $\begin{array}{l}\text { ion (1954) [\$196,975]; Constructed } 1,500 \\
(1960)[\$ 53,607] ; \text { Added 9,593 sqft (date } \\
\text { indows; Blocked windows at courtyard angled } \\
\text { n window openings with stucco; Blocked }\end{array}$ \\
\hline
\end{tabular}




\section{Photographs}

Photo (date):

Caption:
104A.JPG (taken 4/4/2016)

Location map, Main Post

(Map was redacted from publicly released version.)

Photo (date):

Caption:
104B.JPG (taken 4/4/2016)

Southeast oblique, view to north 
Photo (date):

Caption:

104C.JPG (taken 4/4/2016)

East elevation, View to west

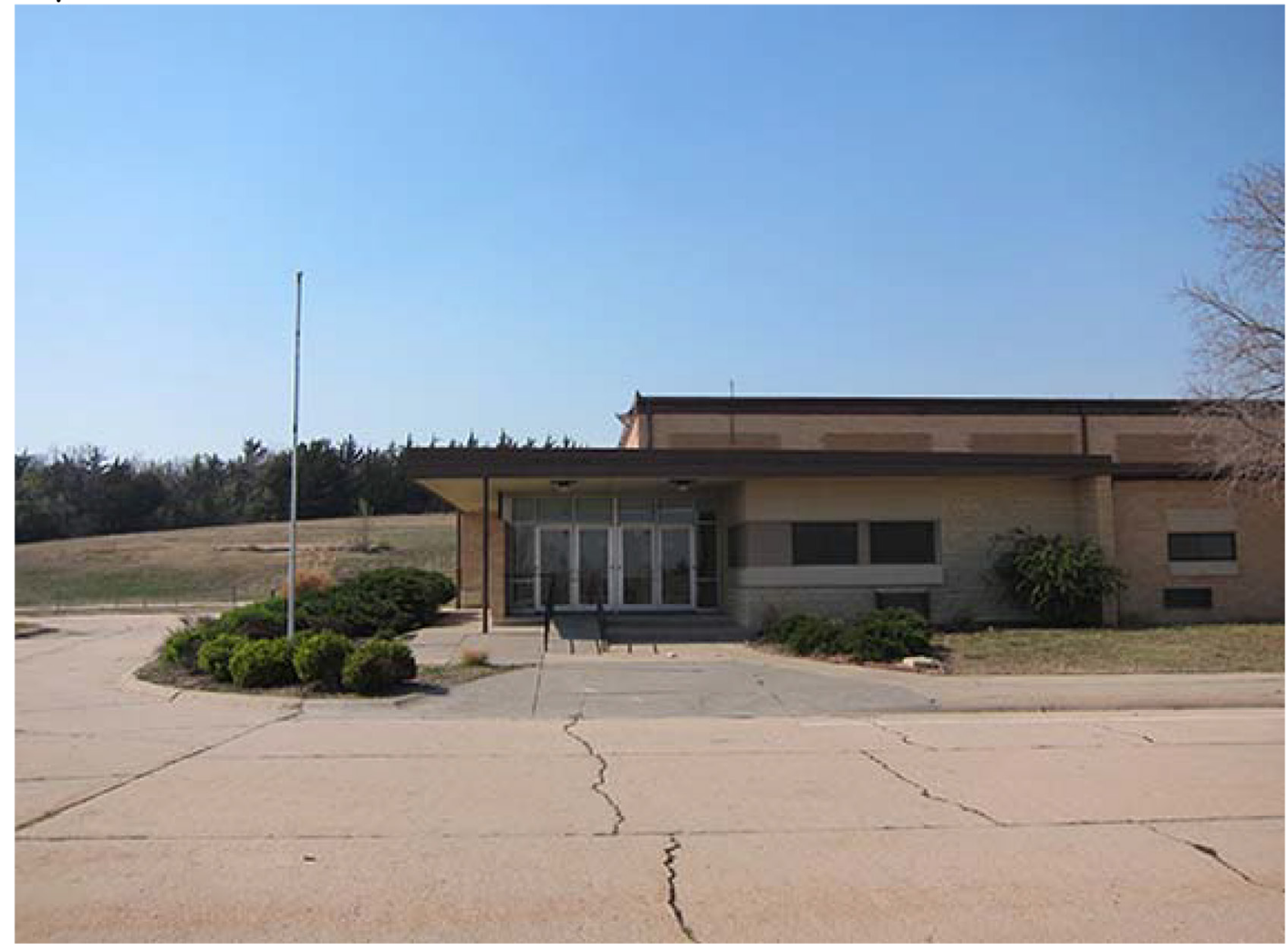

Photo (date):

104D.JPG (taken 4/4/2016)

Caption:

East elevation, view to northwest

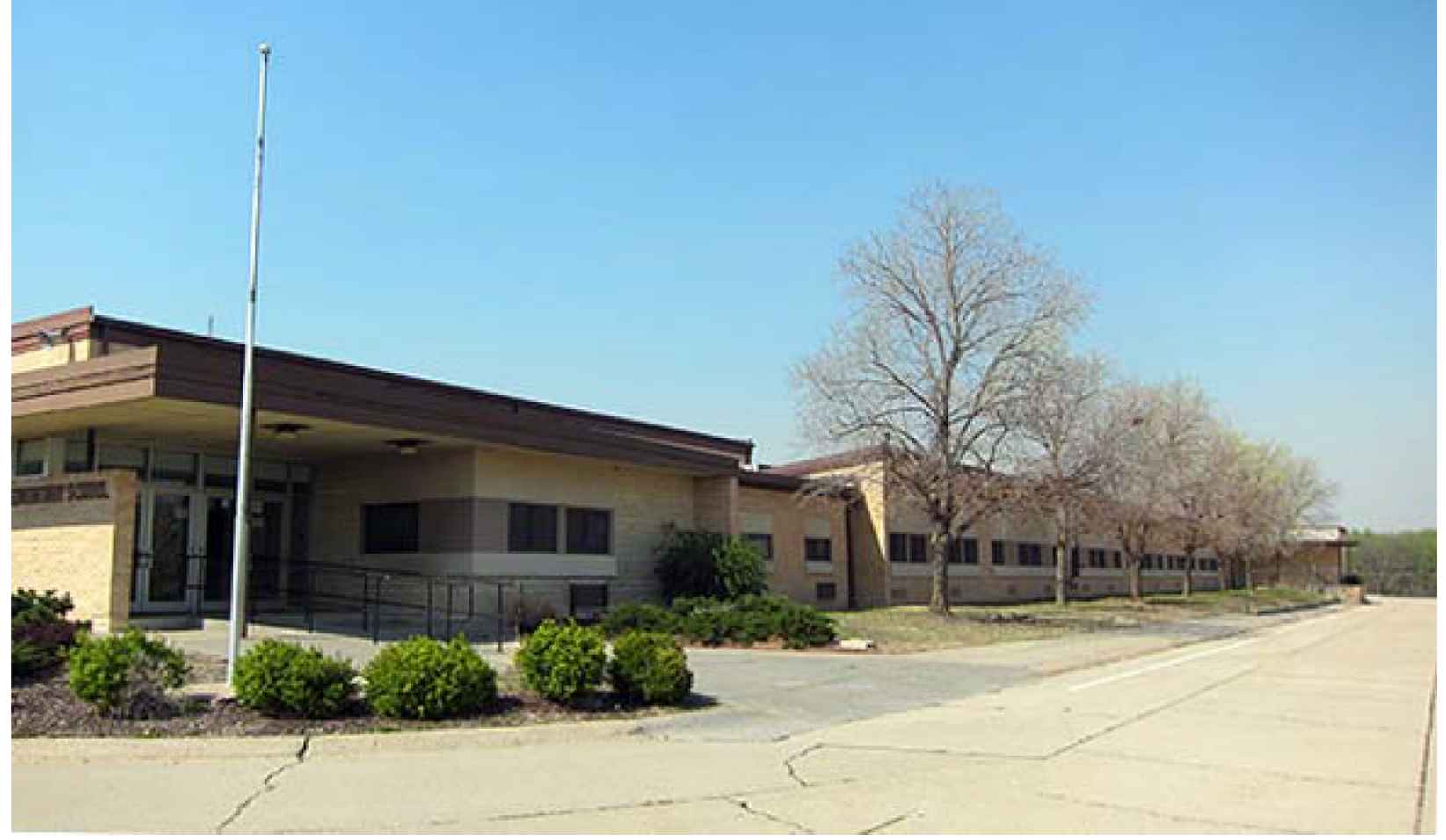


Building\#: 104

Photo (date):

Caption:
104E.JPG (taken 4/4/2016)

East elevation, view to west

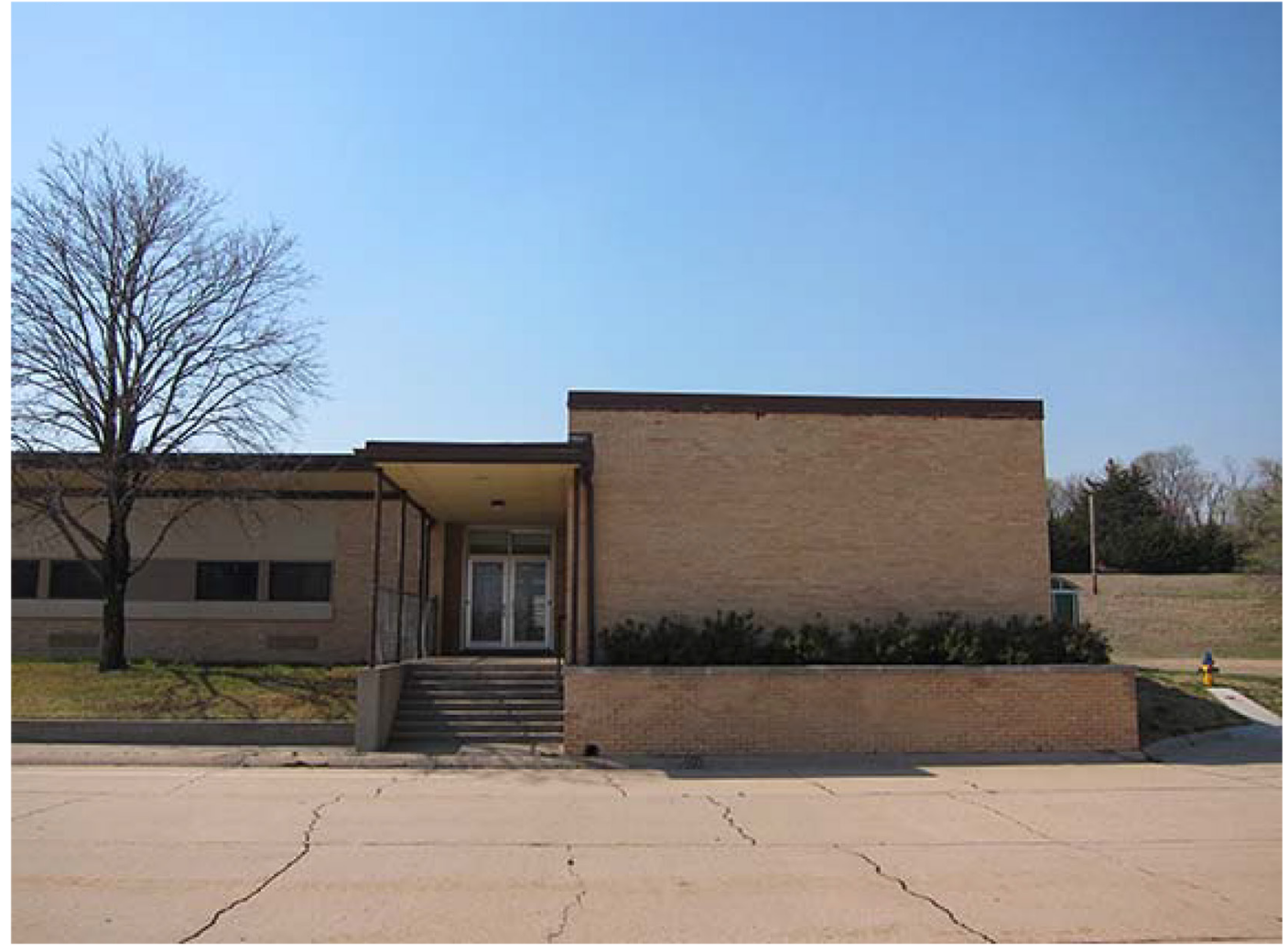

Photo (date):

104F.JPG (taken 4/4/2016)

Caption:

North elevation, view to south

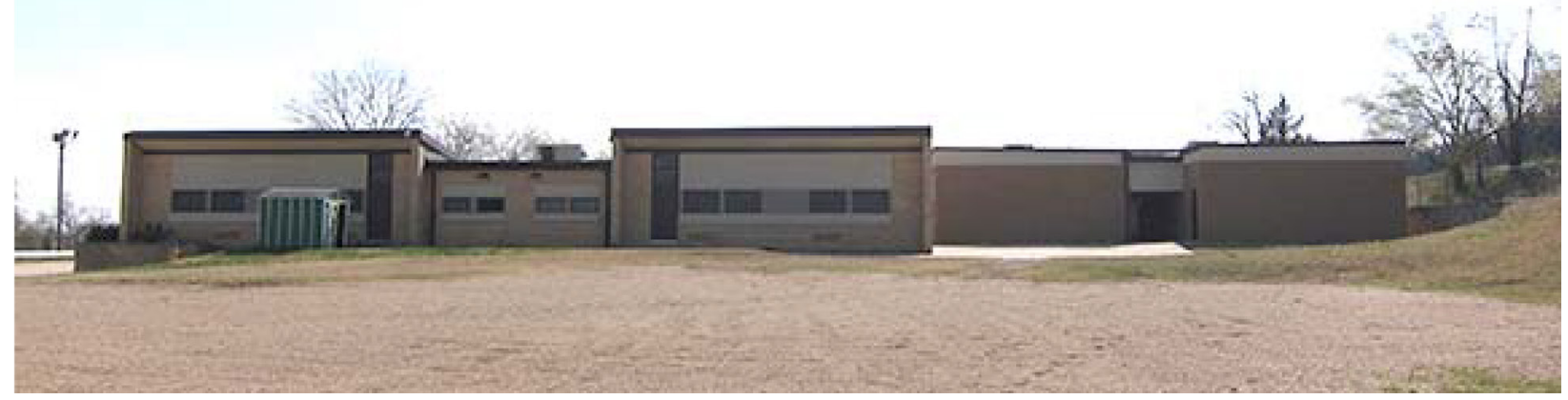


Building\#: 104

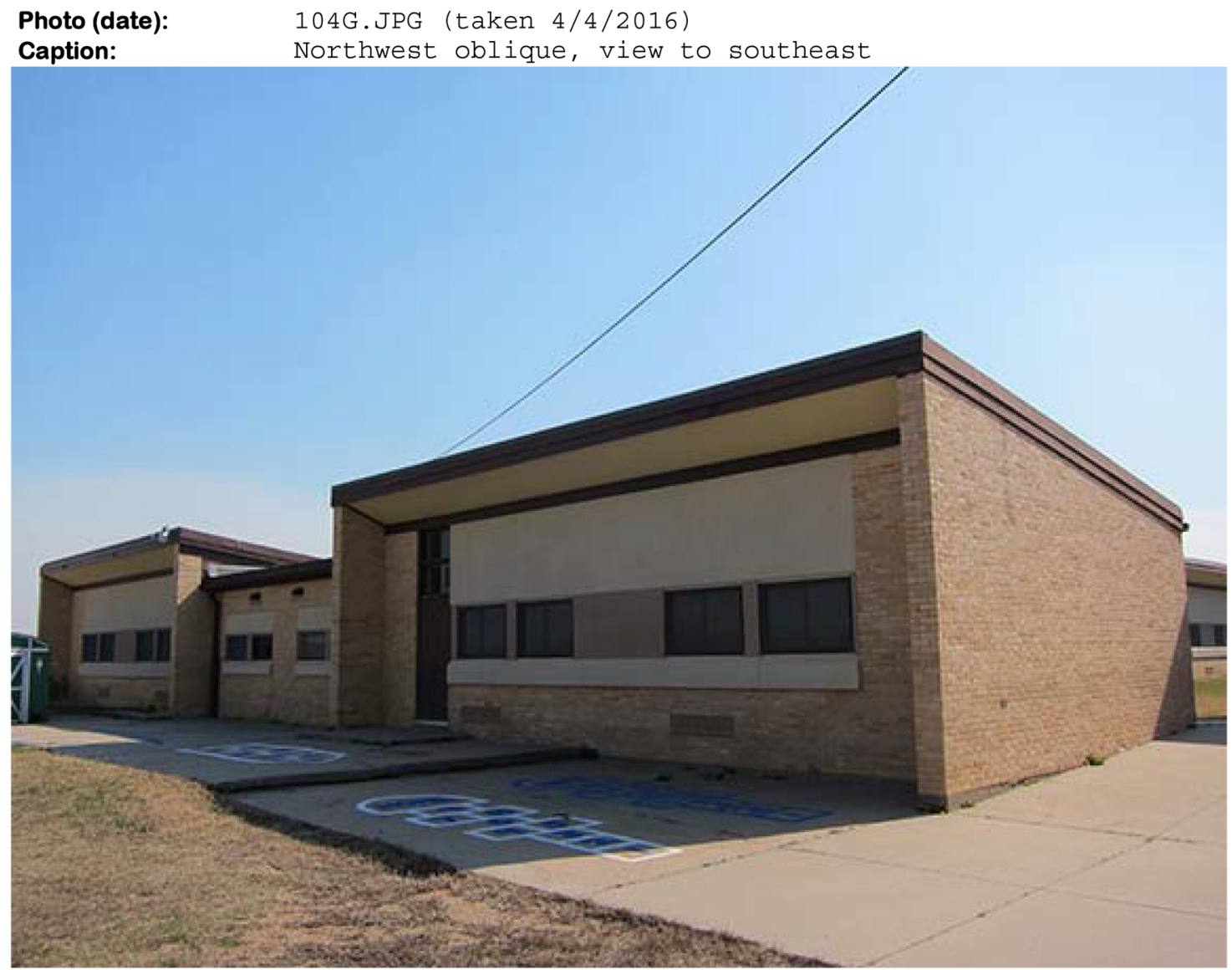

Photo (date):

104H.JPG (taken 4/4/2016)

Caption:

North elevation, view to south

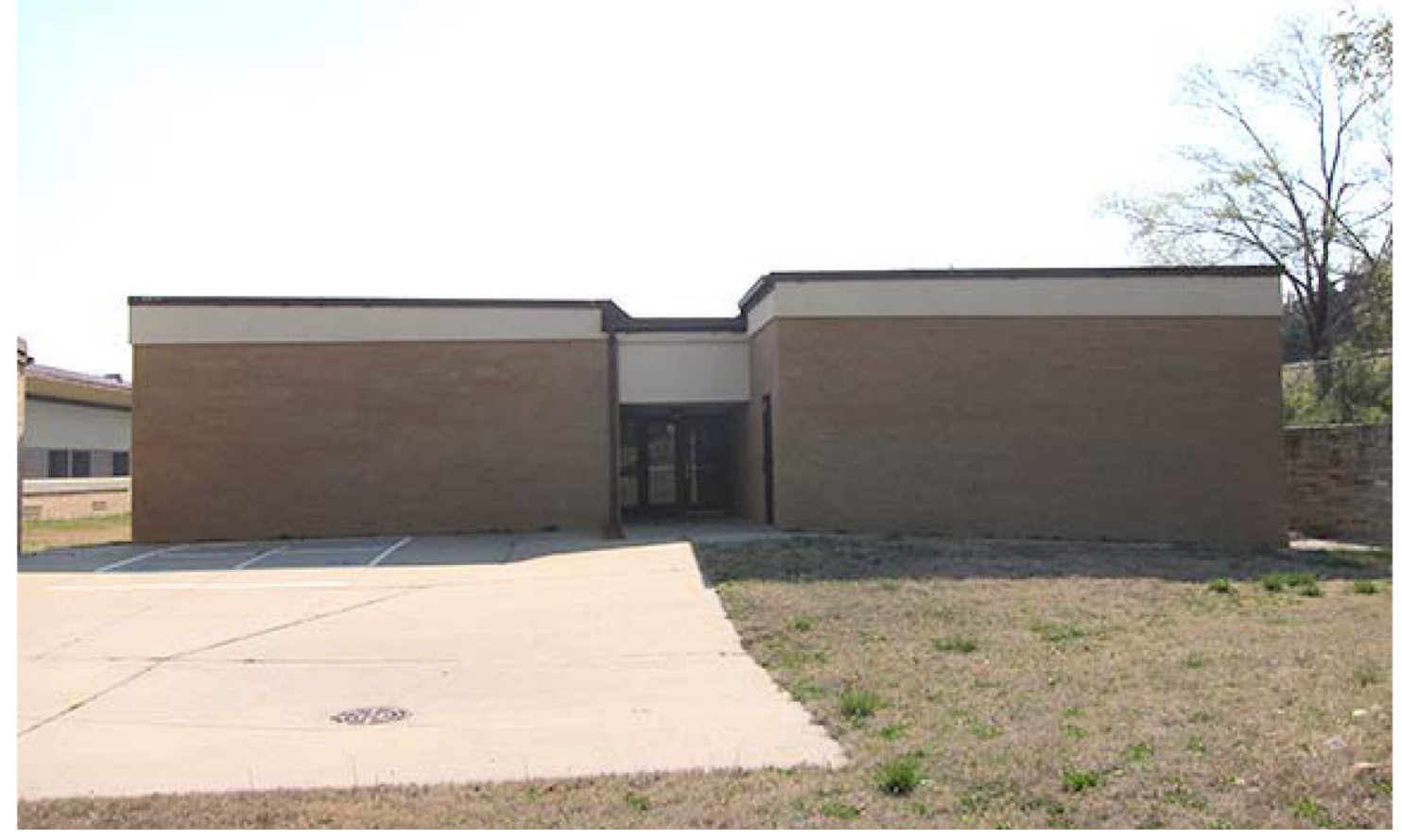


Building\#: 104

Photo (date):

Caption:
104I.JPG (taken 4/4/2016)

West elevation, view to east

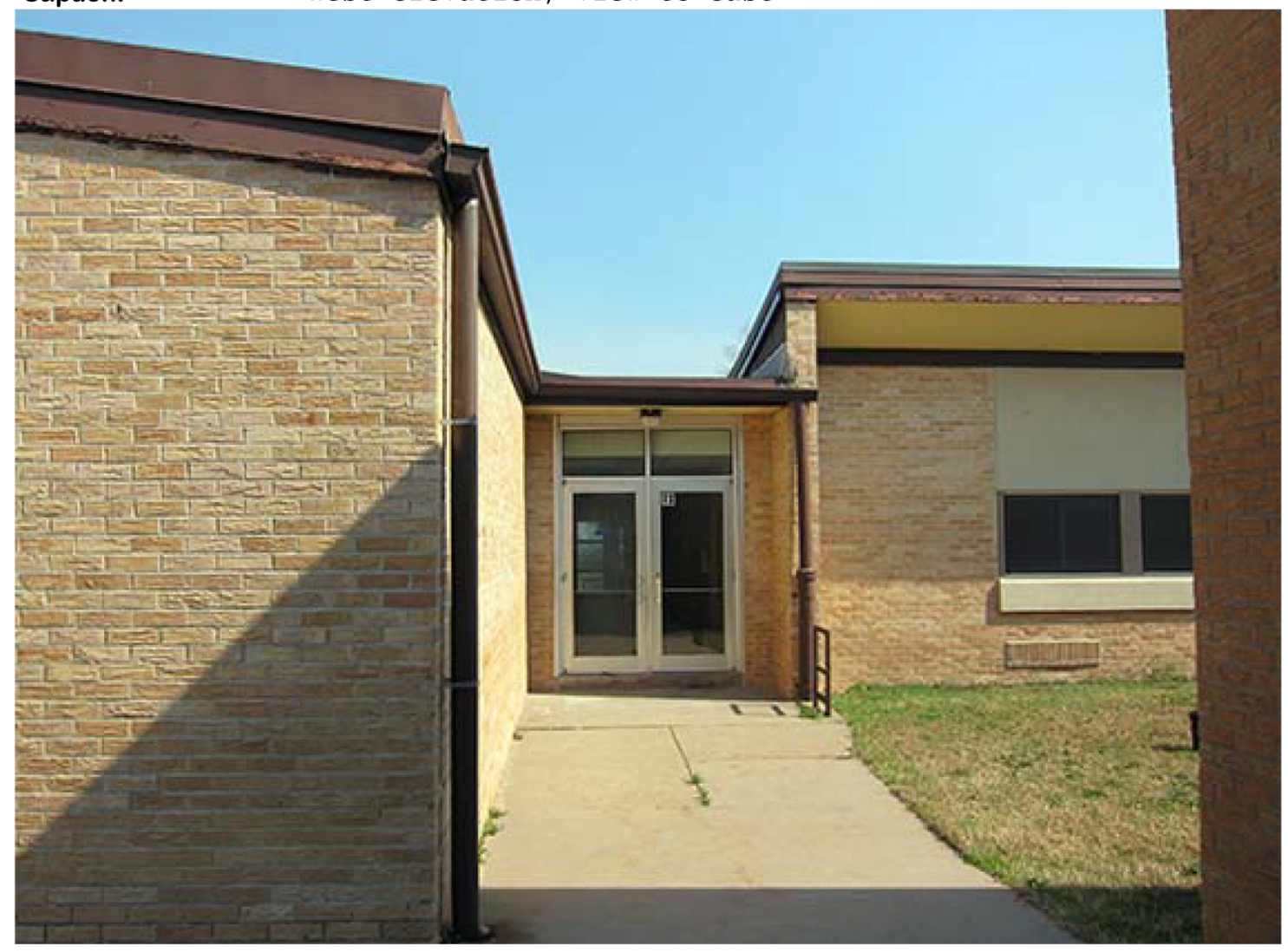

Photo (date):

104J.JPG (taken 4/4/2016)

Caption:

Southwest elevation, view to northwest

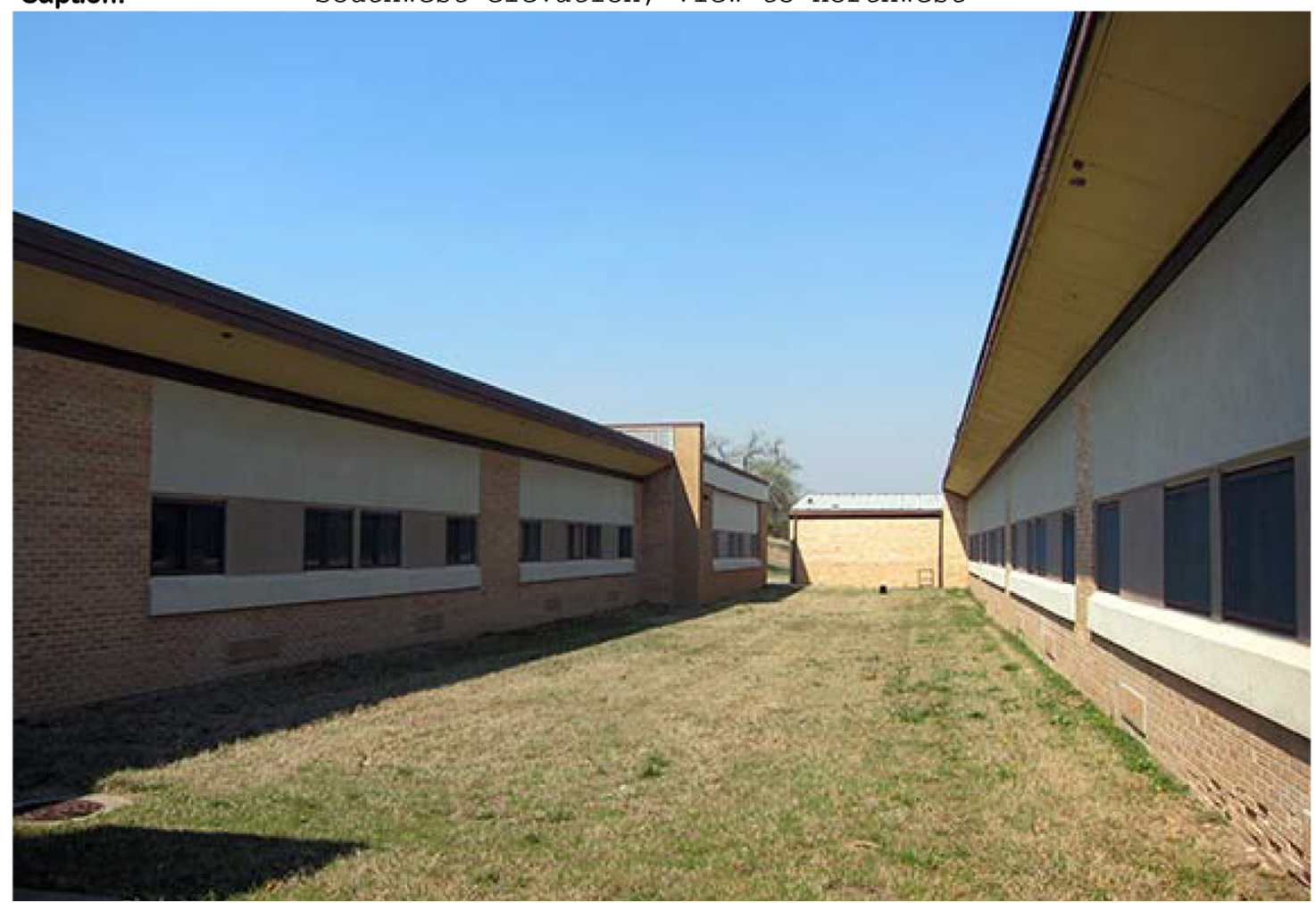


Building\#: 104

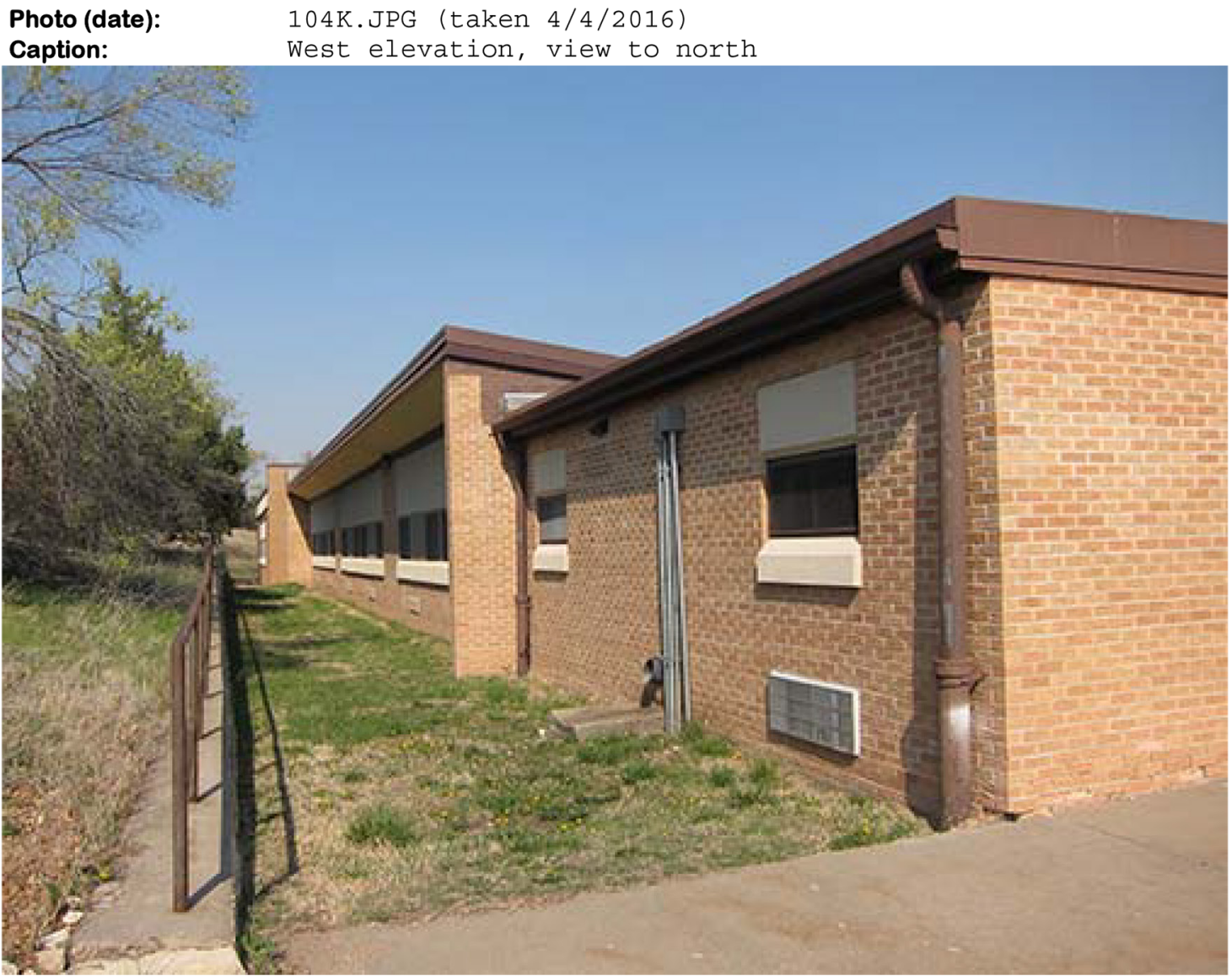
Photo (date):
104L.JPG (taken 4/4/2016)
Caption:
West elevation, view to east 
Building\#: 104

$\begin{array}{ll}\text { Photo (date): } & \text { 104M.JPG (taken } 4 / 4 / 2016) \\ \text { Caption: } & \text { West elevation, view to east }\end{array}$

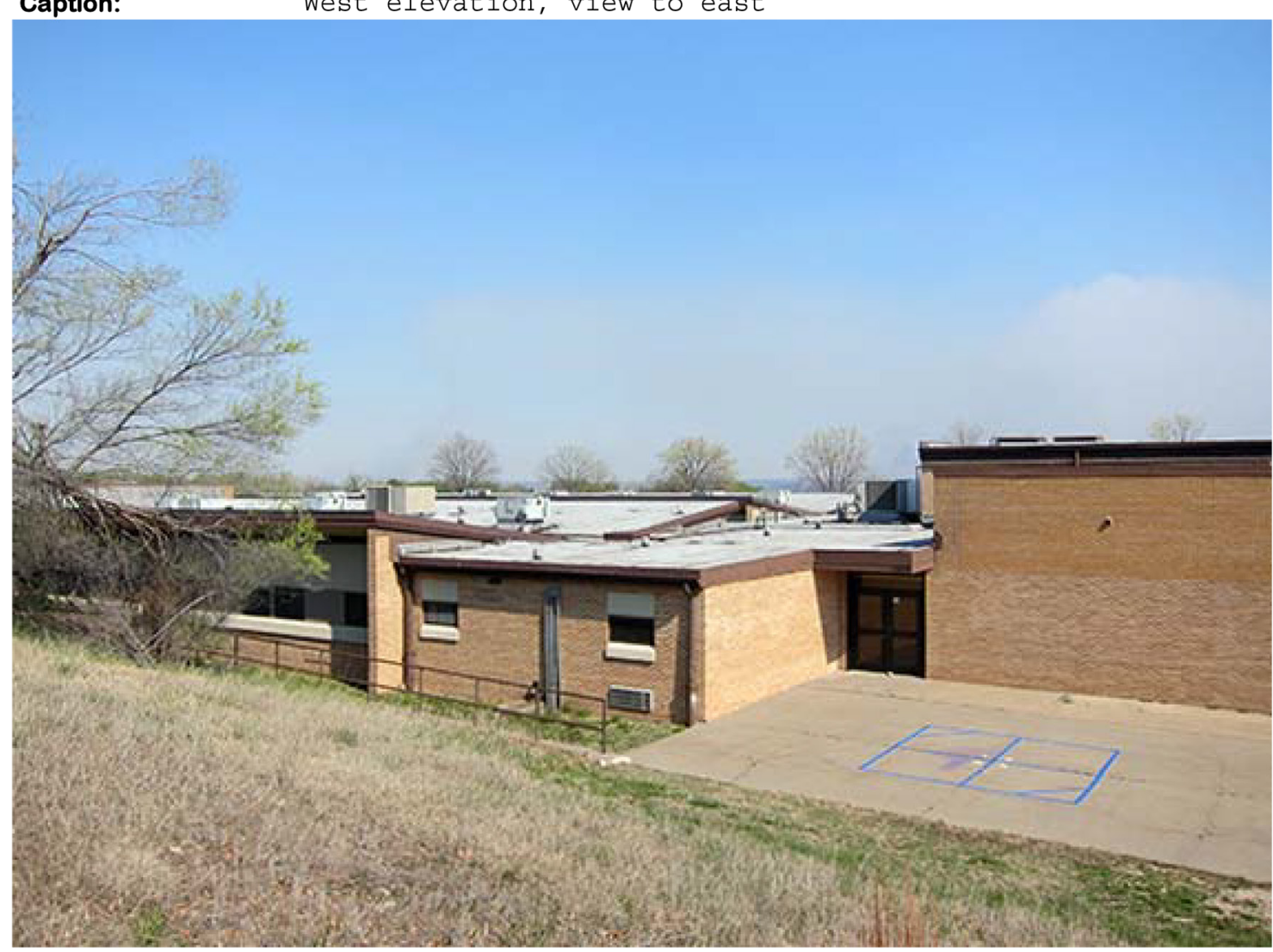

Photo (date):

104N.JPG (taken 4/4/2016)

Caption:

west elevation, view to east

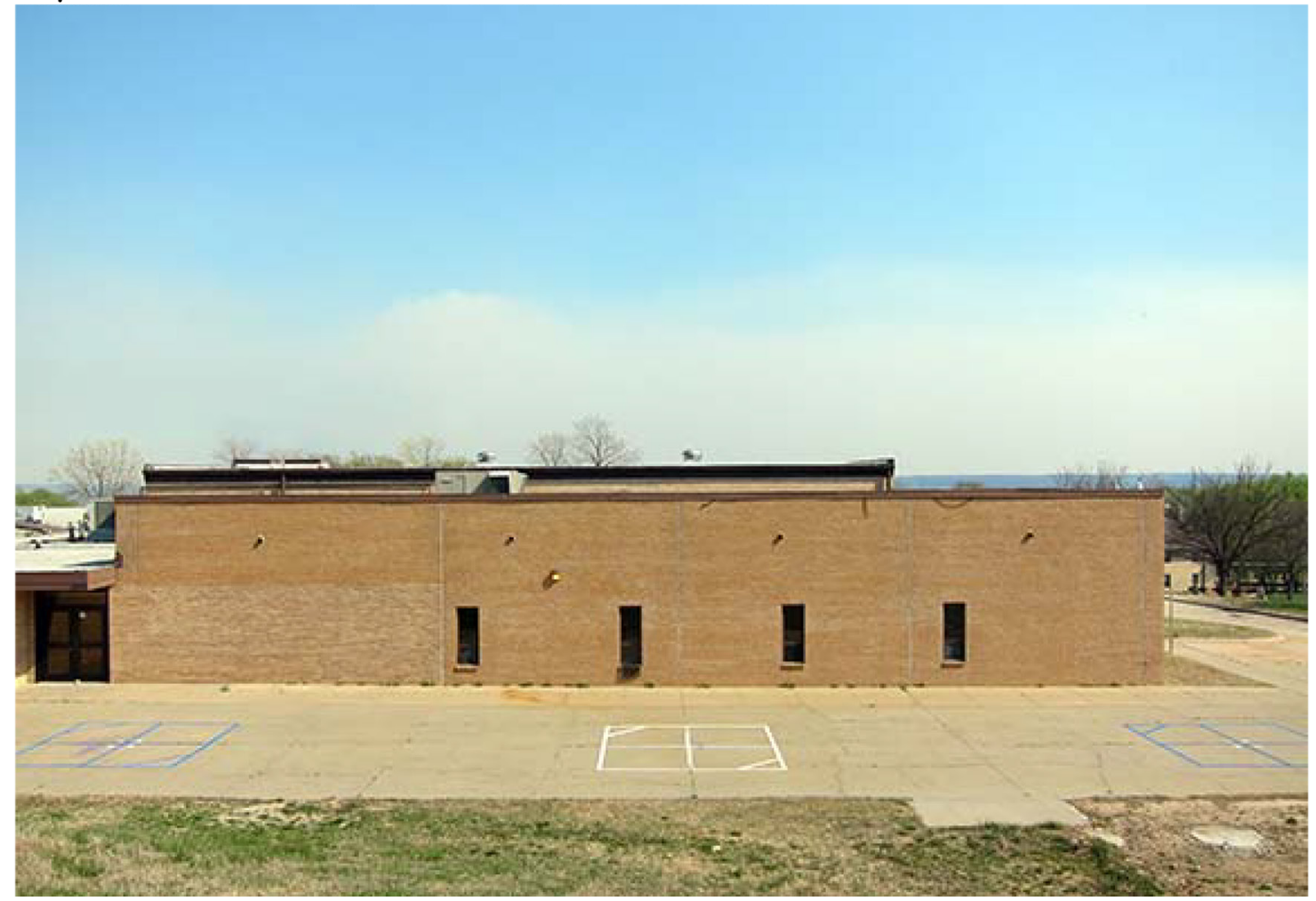


Building\#: 104

Photo (date):

Caption:
Photo (date):

Caption:
1040.JPG (taken 4/4/2016)

Southwest oblique, view to northeast

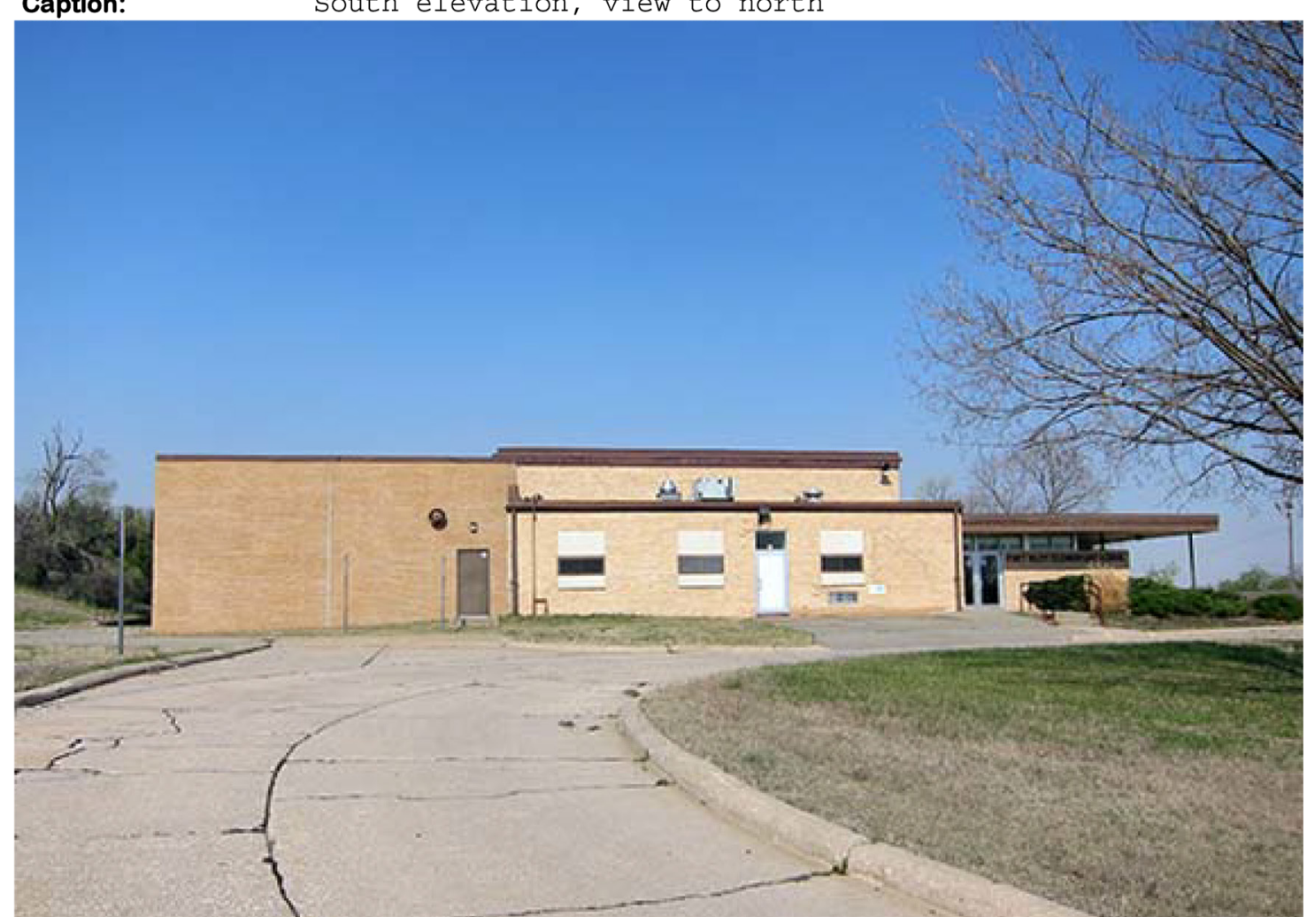


Building\#: 104

Photo (date)

104Q.JPG (taken 4/4/2016)

Caption: South elevation, view to northeast

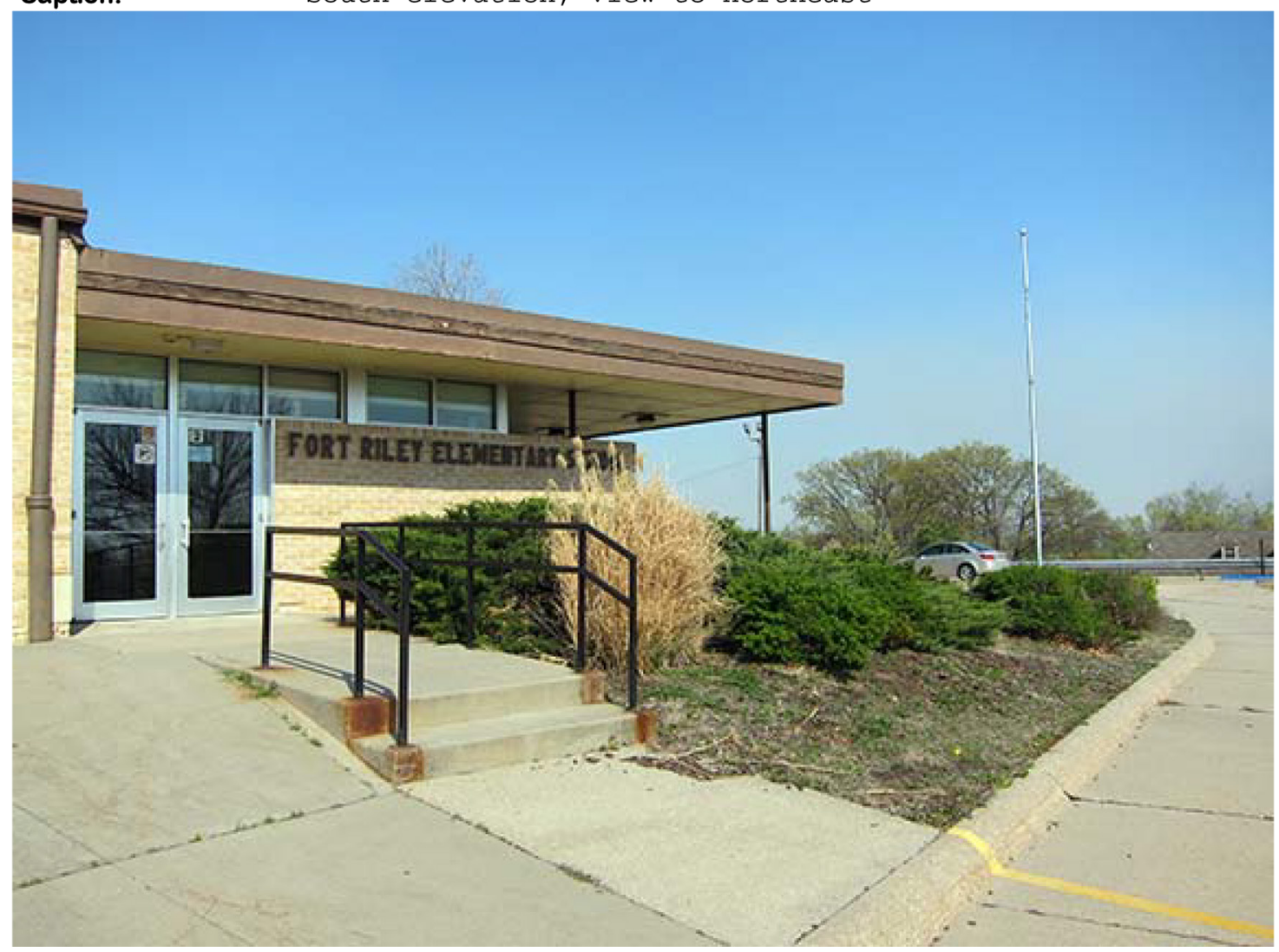


Building\#: 104

VII. Drawings

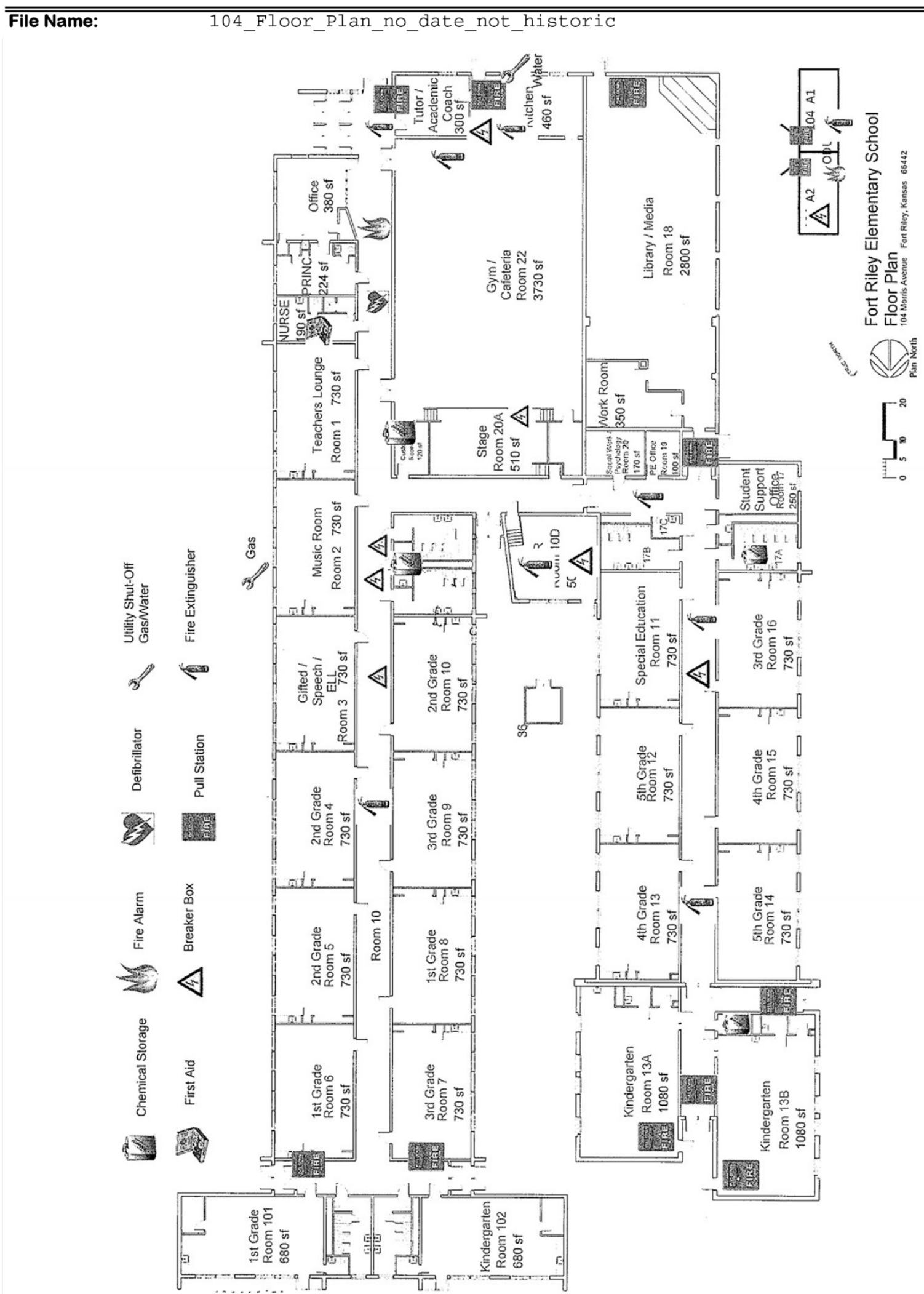


Building\#: 6344

\section{FORT RILEY HISTORIC BUILDING INVENTORY}

\section{Exterior Survey and National Register Evaluation}

\section{Identification}

\begin{tabular}{|c|c|c|c|}
\hline Current Building \#: & 6344 & Owner: & Department of the Army \\
\hline Early Building \#s: & $\mathrm{n} / \mathrm{a}$ & Post Location: & Custer Hill \\
\hline Building Name: & Custer Hill Elementary & Address: & Normandy Drive \\
\hline CATCODE: & 73046 & & \\
\hline Current Use: & (vacant) & & \\
\hline Early Use: & Elementary School & & \\
\hline
\end{tabular}

\section{National Register Eligibility}

\begin{tabular}{|c|c|}
\hline Eligibility Status: & Not Eligible \\
\hline Eligibility Type: & Integrity Aspects: \\
\hline Theme/District: & $\mathrm{n} / \mathrm{a}$ \\
\hline Significance: & $\begin{array}{l}\text { Building } 6344 \text { is recommended not eligible for listing in the NRHP, } \\
\text { either individually or as a contributing resource to a historic } \\
\text { district. It served as a support facility for educating children of } \\
\text { military families on post, playing a tertiary role in the mission of } \\
\text { the installation, and did not serve as a community center or other } \\
\text { focal point at Fort Riley in a social or spatial sense. Although } \\
\text { considered a part of the Geary County Unified School District No. 475, } \\
\text { the schools on post differed in funding, urban-rural perspective, and } \\
\text { federal/state/local policies for district system components from the } \\
\text { surrounding schools. The Fort Riley schools were more aligned with } \\
\text { important national trends than with important state or local trends. } \\
\text { There is no indication that the surveyed property was associated with } \\
\text { the life of an individual significant in United States history. } \\
\text { Facility \#6344's design does not possess any characteristics that } \\
\text { would raise it to the level of significance as an example of } \\
\text { architecture or building construction under the Historic Public } \\
\text { Schools of Kansas NRH multiple property nomination. There is no } \\
\text { indication that the surveyed property has yielded, or is likely to } \\
\text { yield, any information important in prehistory or history beyond what } \\
\text { the real property records, architectural drawings, and archival } \\
\text { research have already yielded. }\end{array}$ \\
\hline
\end{tabular}

\section{Sources of Information}

Fort Riley Directorate of Public Works (DPW) real property database; War Department Form 5-47, Real Property Record - Buildings; DA Form 2877, Real Property Record; DPW Building Directory (2011); drawings on file at Fort Riley DPW; and field observations

\section{Project Information}

Surveyors:

Affiliation:

Survey Dates:
Susan I. Enscore, Julie L. Webster \& Ellen R. Hartman

ERDC-CERL, PO Box 9005, Champaign, IL 61826-9005

19-23 October 2015, 4-6 April 2016 
V. Physical Description

\begin{tabular}{|c|c|c|}
\hline Year Completed: & Condition: & Fair \\
\hline Original Cost: & $\$ 448,642.00$ & Major Modifications \\
\hline Construction Type: & Building Style: & Academic \\
\hline E-file Plan \#: & Area (sqft): & 35,545 \\
\hline Original Plan \#: & Plan Shape: & Irregular \\
\hline Designer: & Stories (\#): & 1 (high bay at gyms) \\
\hline Builder: & Basement: & No \\
\hline Foundation Matl: & $\begin{array}{l}\text { Continuous reinforced } \\
\text { concrete }\end{array}$ & $\begin{array}{l}\text { TYPE (flat); PITCH } \\
\text { (slight); MATL (built-up) }\end{array}$ \\
\hline Structural Material: & $\begin{array}{l}\text { Poured concrete } \\
\text { beams/columns at entry; } \\
\text { Concrete block }\end{array}$ & $\mathrm{n} / \mathrm{a}$ \\
\hline Cladding Material: & Brick (orange) & $\mathrm{n} / \mathrm{a}$ \\
\hline Window \#1: & TYPE (sliding); GROUP (double); MATL (al & um); LITES (2); ORIG (no) \\
\hline Window \#2: & $\mathrm{n} / \mathrm{a}$ & \\
\hline Window \#3: & $\mathrm{n} / \mathrm{a}$ & \\
\hline Door \#1: & TYPE (storefront); GROUP (double); MATL & minum); ORIG (yes) \\
\hline Door \#2: & TYPE (storefront); GROUP (single); MATL & minum); ORIG (no) \\
\hline Door \#3: & TYPE (flush); GROUP (single \& double); & (steel); ORIG (no) \\
\hline Porch \#1: & $\begin{array}{l}\text { open recessed at main entry; poured con } \\
\text { chamfered concrete columns }\end{array}$ & ; frame/roof exposed; \\
\hline Porch \#2: & $\begin{array}{l}\text { at } \mathrm{SW} \text { and NW entry from playground is } r e \\
\text { structure }\end{array}$ & ed; exposed 2-way concrete \\
\hline Porch \#3: & $\mathrm{n} / \mathrm{a}$ & \\
\hline Other Features: & $\begin{array}{l}\text { ARCHITECTURAL - Aluminum coping; Dryvit } \\
\text { Electrical transformer enclosed with dog } \\
\text { separation walls; Exposed corner eaves } \\
\text { LANDSCAPE - Flag pole at main entry; Pla } \\
\text { three gabled, rectangular, modular outbu } \\
\text { walls \& roof, one with vertical T\&G wood } \\
\text { Modulars have wood ramps, decks \& rails; } \\
\text { side }\end{array}$ & $\begin{array}{l}\text { s; Roof ladder at gym; } \\
\text { fencing; Visible fire } \\
\text { nd corner columns; } \\
\text { und; Concrete play area; } \\
\text { ngs (one with metal seam } \\
\text { rds \& asphalt shingles); } \\
\text { king lots at front \& south }\end{array}$ \\
\hline Alterations/Addns: & $\begin{array}{l}\text { Replaced doors \& windows; Original ribl } \\
\text { Dryvit; Blocked north door opening; Bl }\end{array}$ & $\begin{array}{l}\text { dows infilled w/stucco } \\
\text { rawlspace openings. }\end{array}$ \\
\hline
\end{tabular}




\section{Photographs}

Photo (date): $\quad$ 6344A.JPG (taken 4/4/2016)

Caption:

Location map, Custer Hill

Map was redacted from publicly available version.

Photo (date):

Caption:

6344B.JPG (taken 4/4/2016)

Southeast oblique, view to northwest

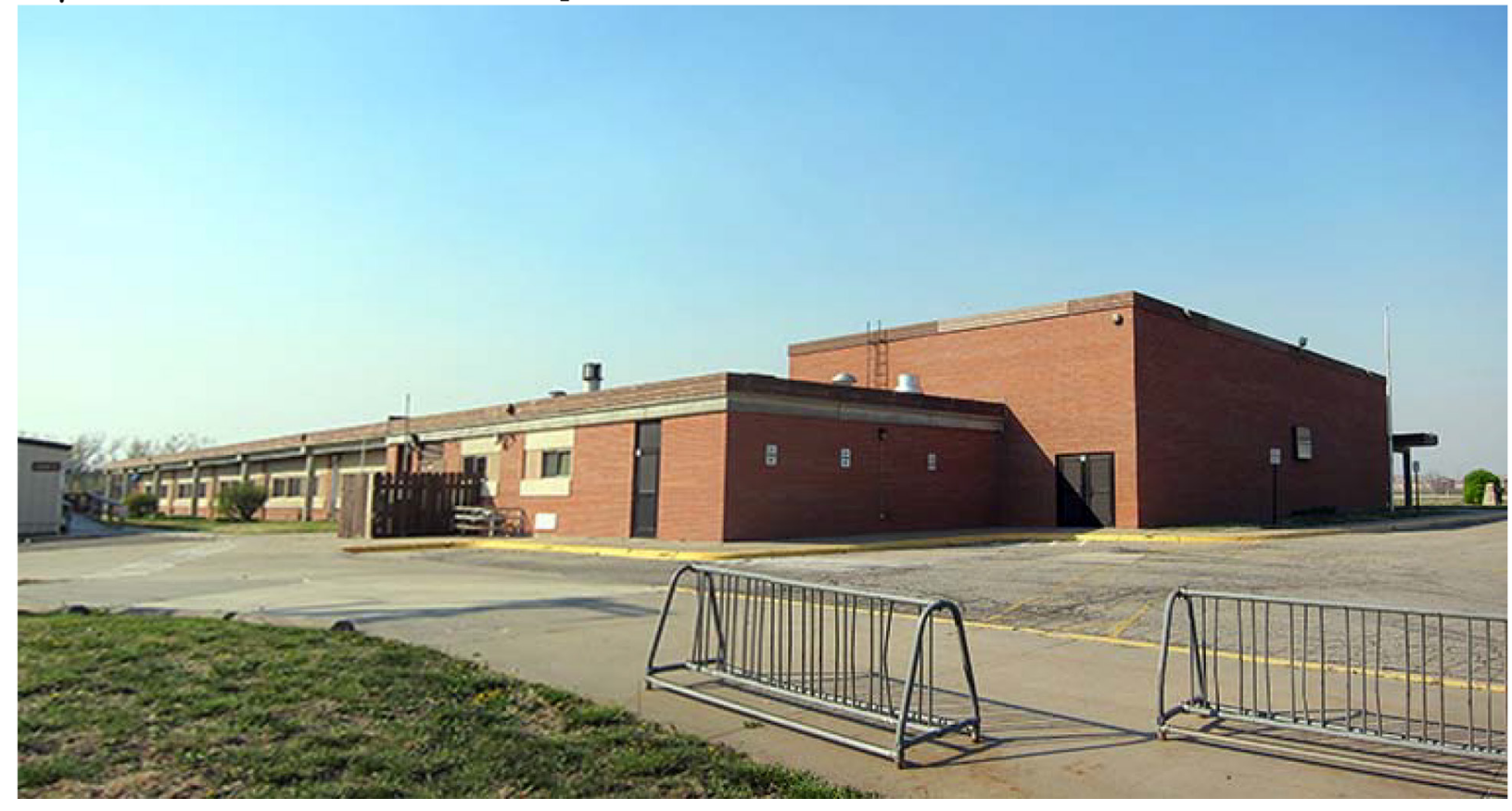


Building\#: 6344

Photo (date):

Caption:
6344C.JPG (taken 4/4/2016)

East elevation, view to west

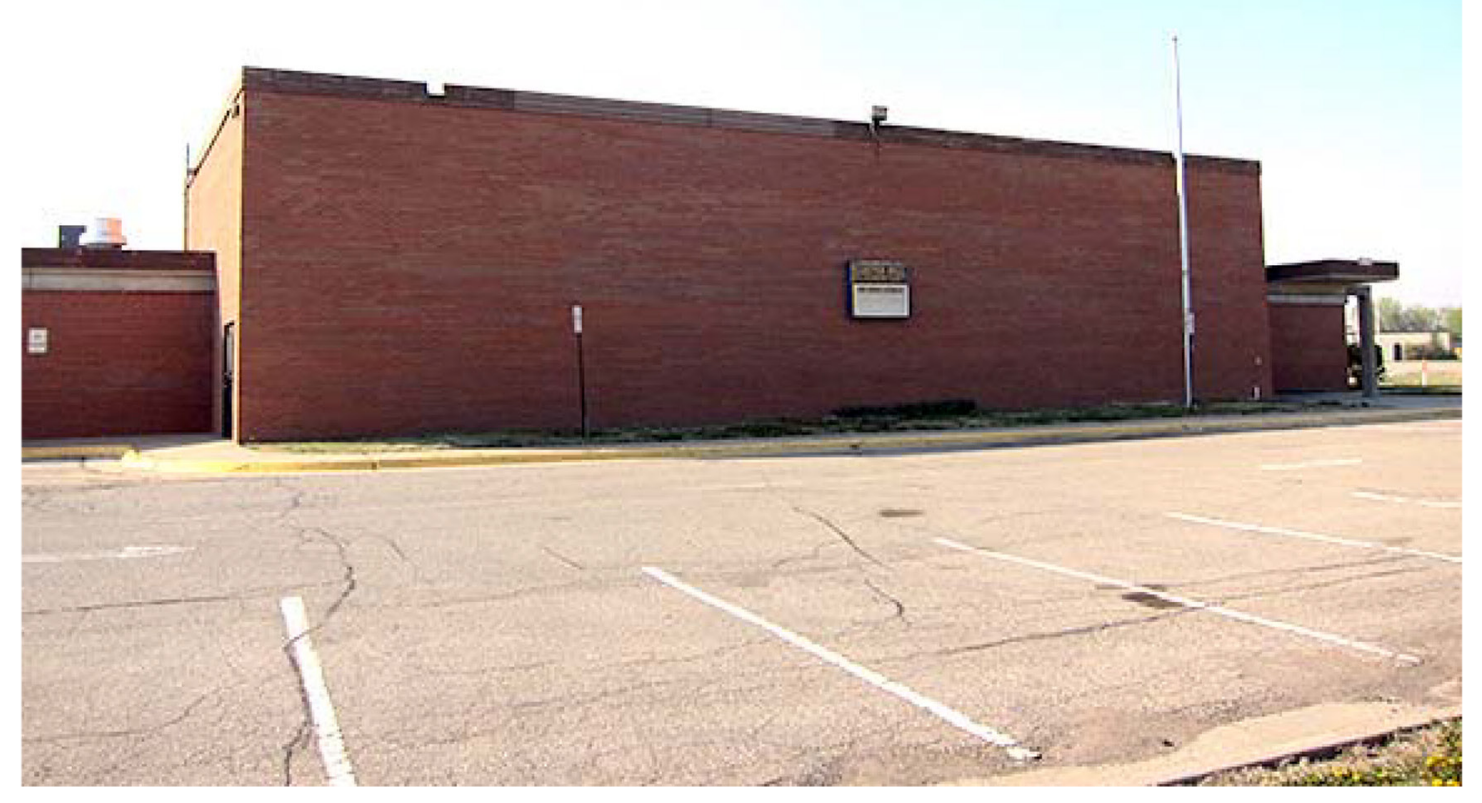

Photo (date):

Caption:
6344D.JPG (taken 4/4/2016)

North elevation, view to south

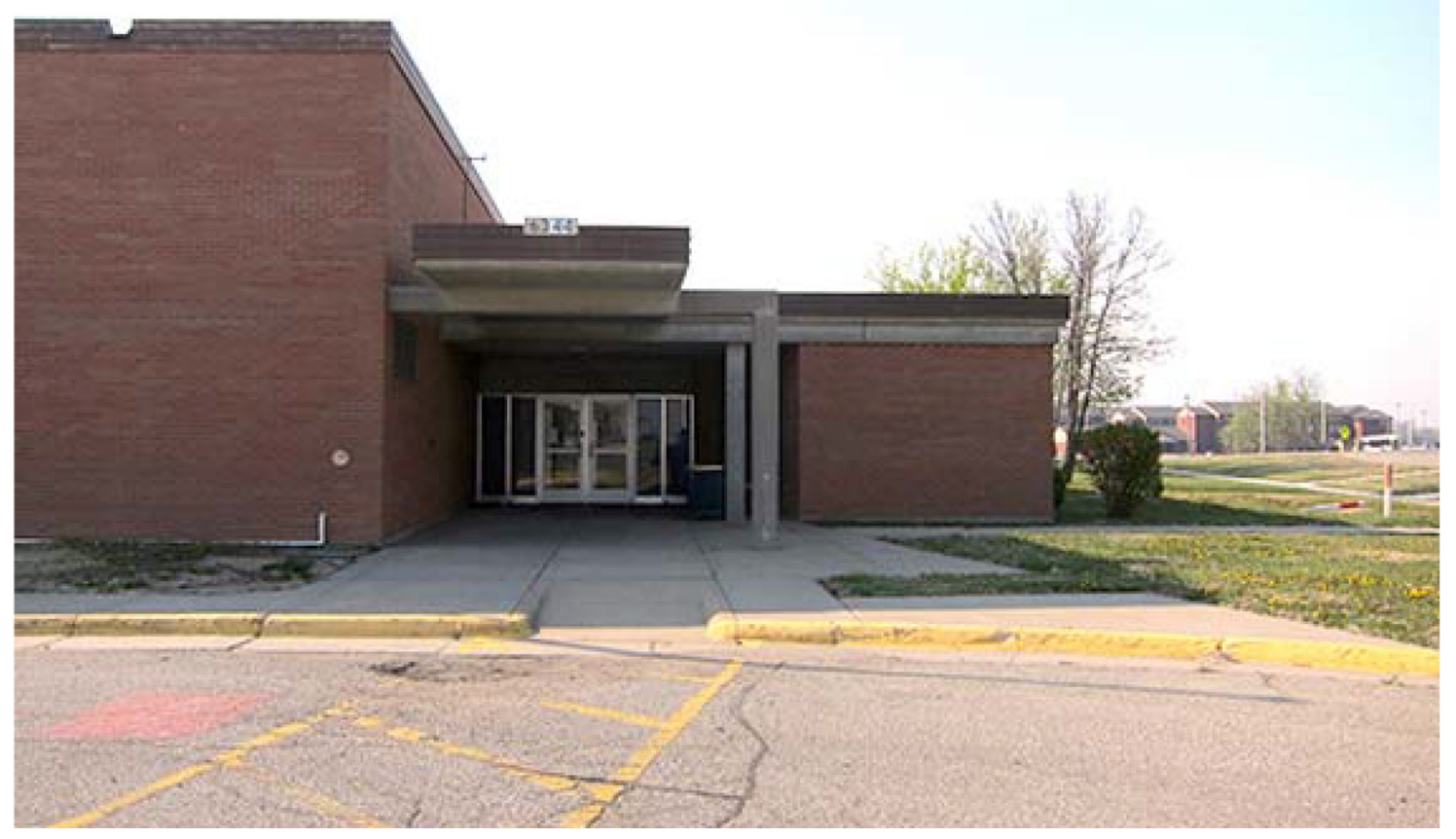


Photo (date):

Caption:
6344E.JPG (taken 4/4/2016)

Northeast oblique, view to southwest

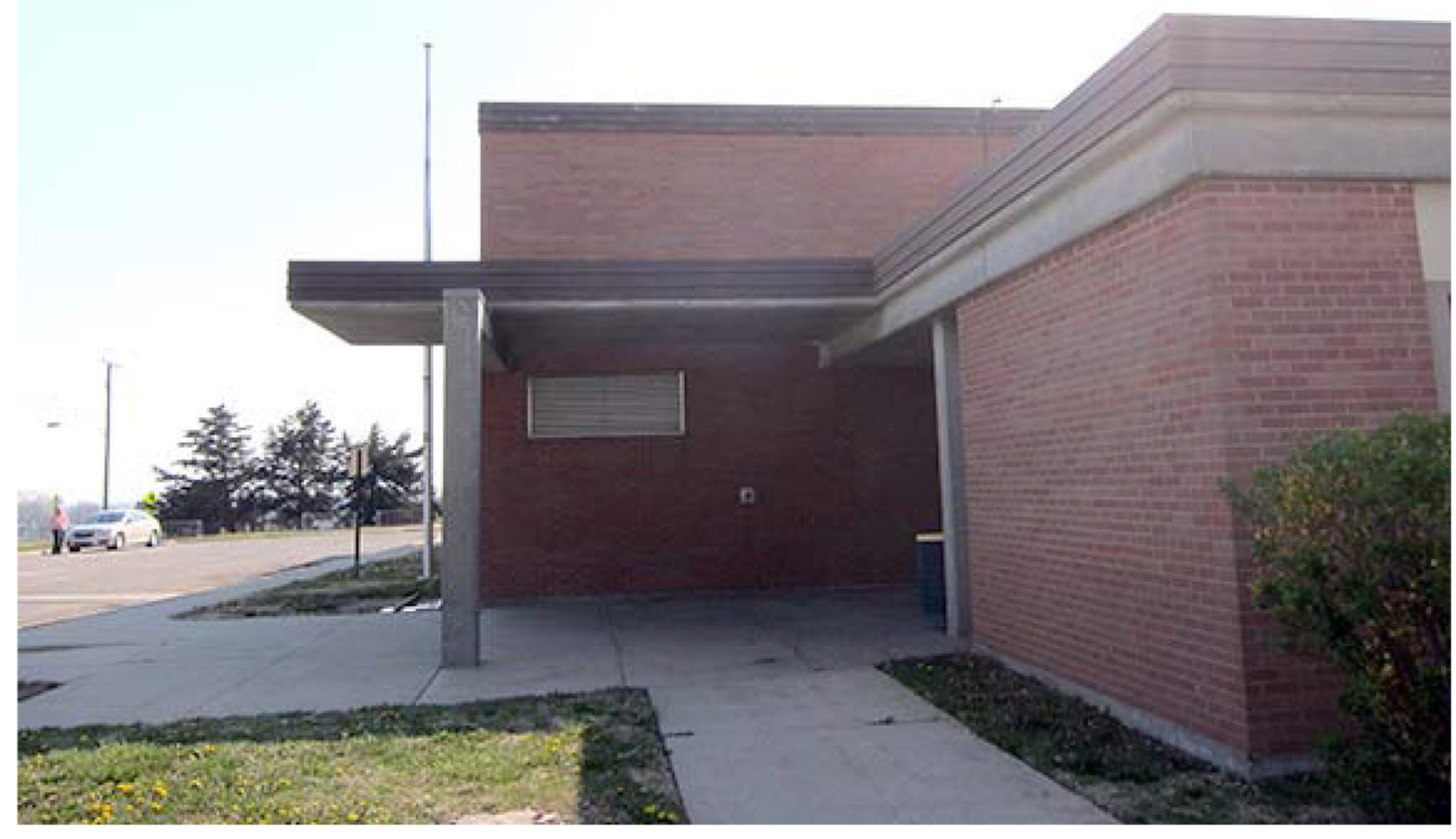

Photo (date):

Caption:
6344F.JPG (taken 4/4/2016)

Northwest oblique, view to southeast 
Photo (date):

6344G.JPG (taken 4/4/2016)

Caption: West elevation, view to east

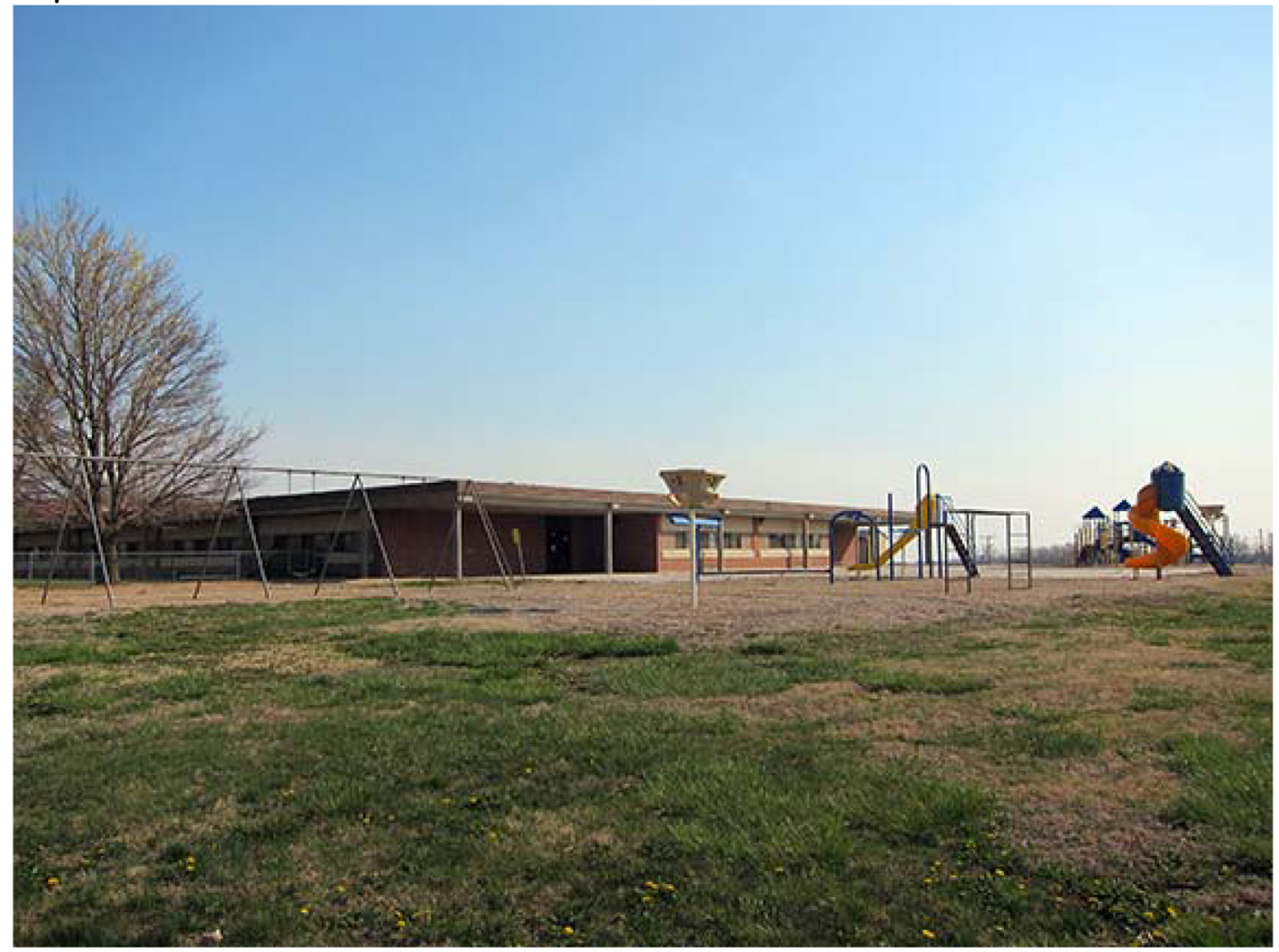

Photo (date):

6344H.JPG (taken 4/4/2016)

Caption:

Southwest oblique, view to northeast

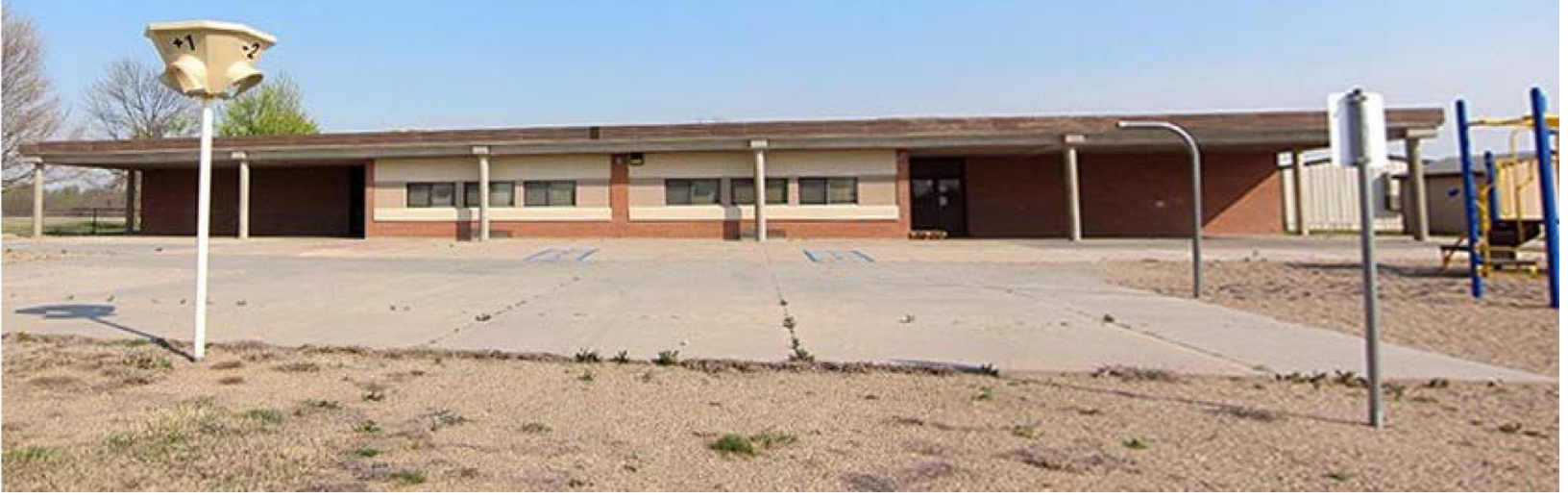


Photo (date):

6344I.JPG (taken 4/4/2016)

Caption: Southeast oblique, view to northwest

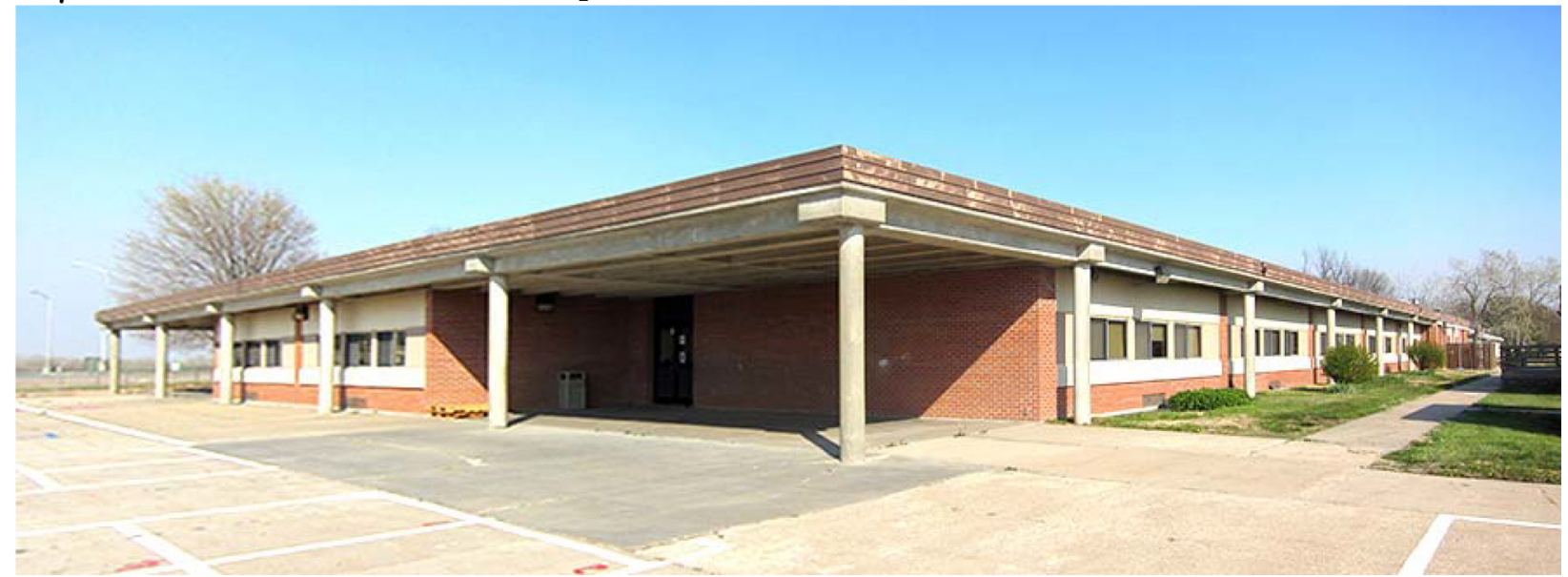

Photo (date):

Caption:

6344J.JPG (taken 4/4/2016)

South elevation, view to north

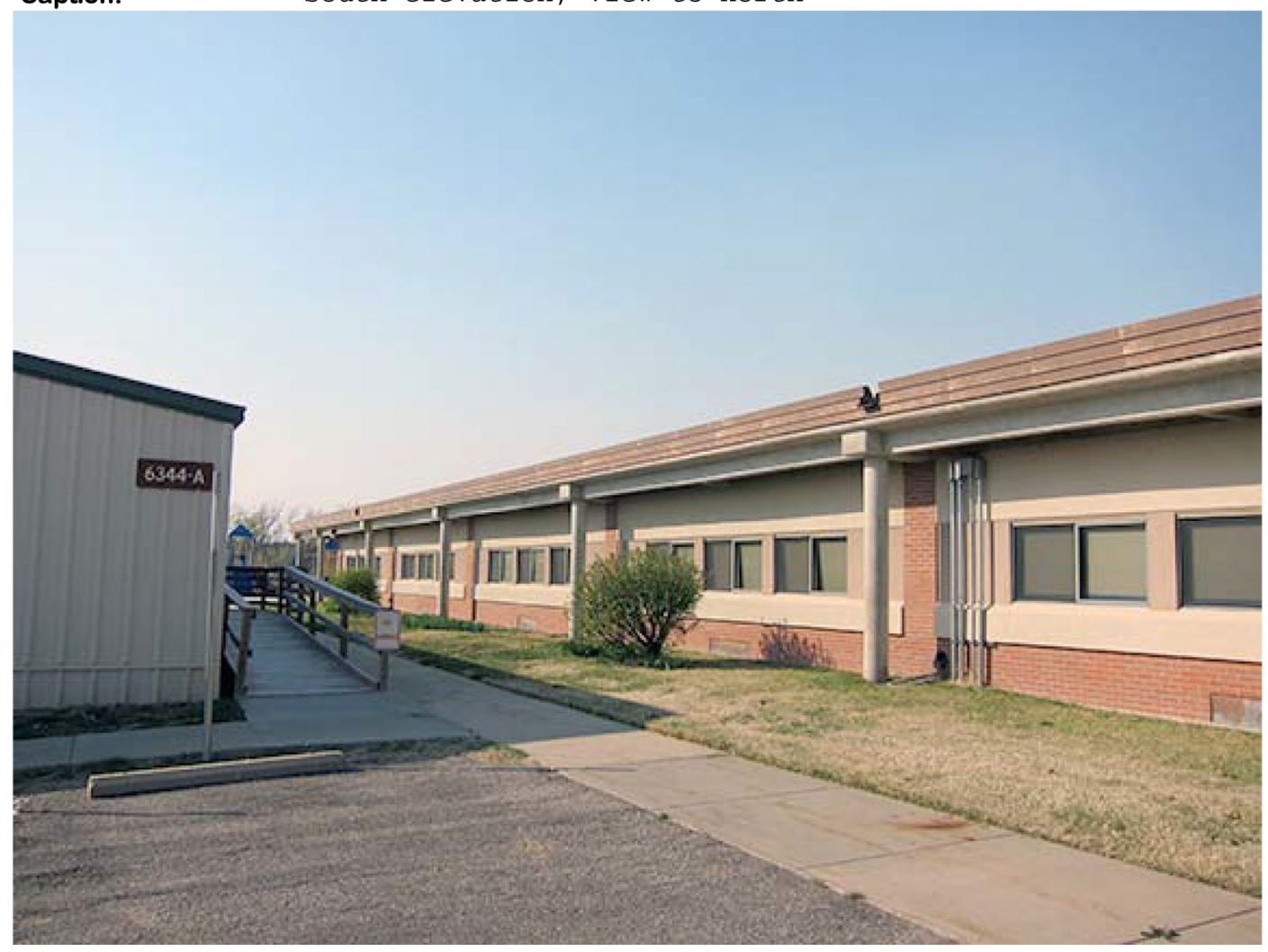


Building\#: 6344

Photo (date):

6344K.JPG (taken 4/4/2016)

Caption:

Southeast oblique, view to northwest

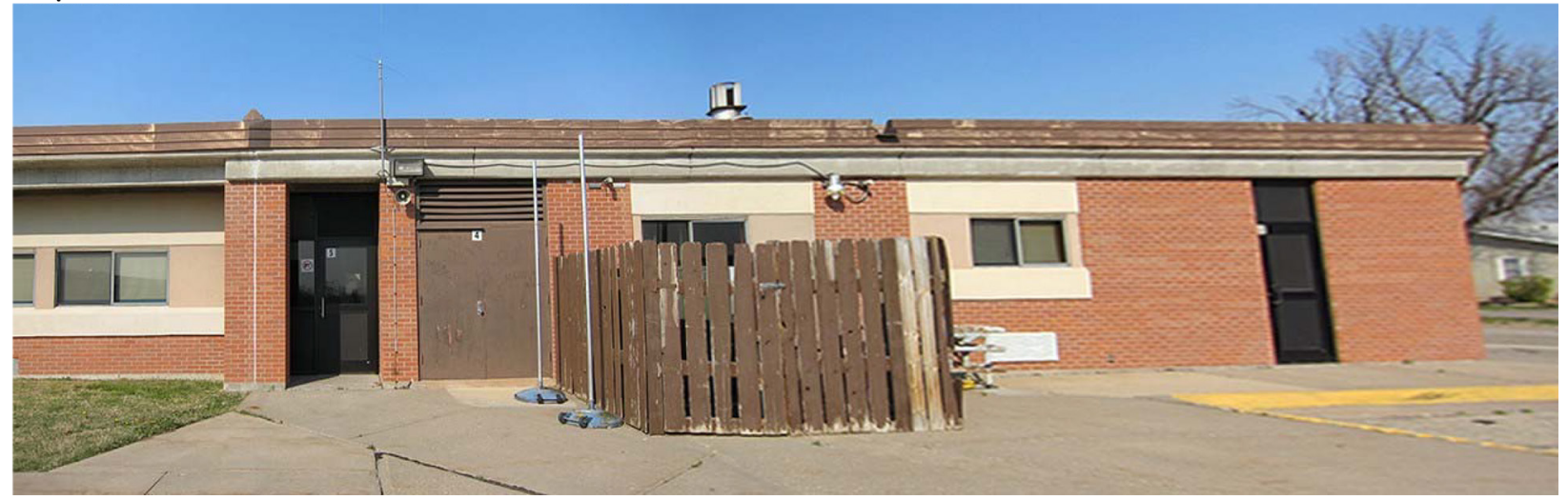




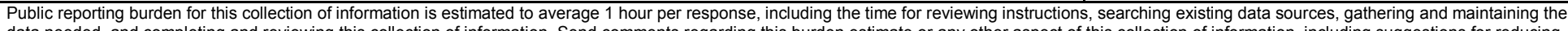

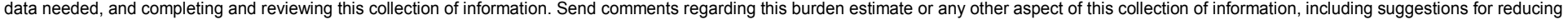

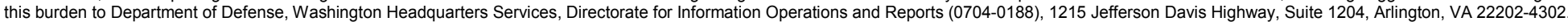

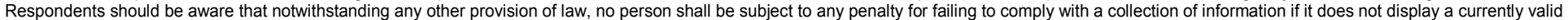
OMB control number. PLEASE DO NOT RETURN YOUR FORM TO THE ABOVE ADDRESS.

\begin{tabular}{l|l|l} 
OMB control number. PLEASE DO NOT RETURN YOUR FORM TO THE ABOVE ADDRESS. \\
\hline 1. REPORT DATE (DD-MM-YYYY) & 2. REPORT TYPE & 3. DATES COVERED (FrOm - To)
\end{tabular}

\section{TITLE AND SUBTITLE}

Final Technical Report

Inventory and Evaluation for Fort Riley Elementary School (\#104) and Custer Hill

Elementary School (\#6344), Fort Riley, Kansas

5a. CONTRACT NUMBER

5c. PROGRAM ELEMENT NUMBER

6. AUTHOR(S)

Susan I. Enscore, Ellen R. Hartman, and Julie L. Webster

5d. PROJECT NUMBER

453125

5e. TASK NUMBER

MIPR 10697109

5f. WORK UNIT NUMBER

8. PERFORMING ORGANIZATION REPORT NUMBER

ERDC/CERL TR-17-14

U.S. Army Engineer Research and Development Center (ERDC)

Construction Engineering Research Laboratory (CERL)

PO Box 9005

Champaign, IL 61826-9005

\section{SPONSORING / MONITORING AGENCY NAME(S) AND ADDRESS(ES)}

Cultural Resources Office

Conservation Branch,-Environmental Division

Fort Riley, Kansas 66442

\section{DISTRIBUTION / AVAILABILITY STATEMENT}

Approved for public release. Distribution is unlimited.

\section{SUPPLEMENTARY NOTES}

\section{ABSTRACT}

This report documents an architectural survey and evaluation of two former school buildings at Fort Riley, Kansas, constructed in 1952 and 1963. This report includes a concise historic context, an architectural description and history for each building, and a determination of each building's eligibility to the National Register of Historic Places (NRHP). The Fort Riley Elementary School and the Custer Hill Elementary School were evaluated against relevant criteria for the existing historical themes related to Fort Riley and also against relevant criteria for the NRHP Multiple Property Historic District: Historic Public Schools of Kansas. It was found that both the Fort Riley Elementary School and the Custer Hill Elementary School did not meet significance criteria for eligibility to the NRHP, and are therefore recommended to be not eligible to the NRHP.

\section{SUBJECT TERMS}

Historic buildings, Historic preservation, Architectural surveys, National Register of Historic Places, Fort Riley (Kan.)

\section{SECURITY CLASSIFICATION OF:}

\section{a. REPORT}

Unclassified

\section{b. ABSTRACT \\ Unclassified}

\section{LIMITATION} OF ABSTRAC

c. THIS PAGE

Unclassified
18. NUMBER OF PAGES

UU

\section{NUMBER(S)}

10. SPONSOR/MONITOR'S ACRONYM(S)

11. SPONSOR/MONITOR'S REPORT 